\title{
"To Which Constitution the Further Laws of the Present Sejm Have to Adhere to in All..." Constitutional \\ Precedence of the 3 May System
}

\author{
Anna Tarnowska
}

\section{Contents}

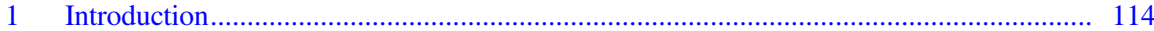

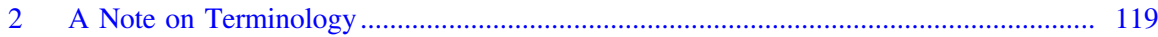

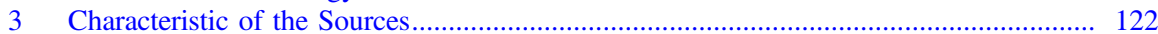

4 French Inspirations of Polish Republicans: Drafts of Mably and Rousseau .................... 124

5 The Extraordinary Procedure for Enactment of the Constitution of 3 May:

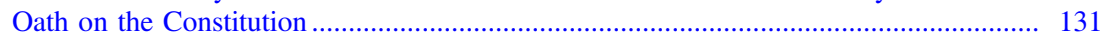

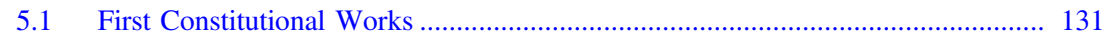

5.2 Enactment of the Government Statute ............................................................. 134

$5.3 \quad$ An Oath on the Constitution ............................................................................ 137

6 The Problem of the Supreme Law in the Time of the 3 May Debate ........................... 142

6.1 Henrician Articles and Pacta Conventa ................................................................ 142

6.2 Cardinal Laws in Polish Tradition and Legal System.......................................... 145

7 Relation Between the Constitution and the Ordinary Legislation:

Nullification of the Law Contravening to the Constitution.............................................. 153

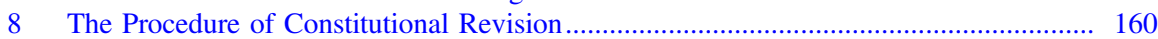

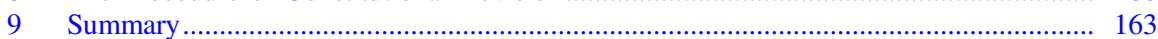

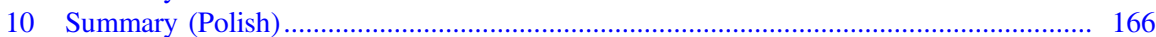

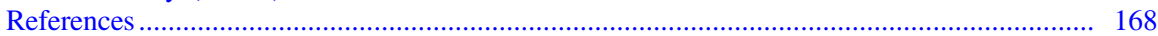

\begin{abstract}
Understanding of the principle of constitutional precedence raises numerous doubts in the Polish case. Although this rule was stated expressis verbis in the Declaration of the Assembled Estates from 5 May 1791 joining May Constitution, following studies allow for the ascertainment that its content and significance for the legal order was perceived differently. In light of experienced practice, we may not accept without reservations the claim of a general recognition
\end{abstract}

\footnotetext{
A. Tarnowska $(\bowtie)$

Nicolaus Copernicus University Toruń, Toruń, Poland

e-mail: atarnowska@tlen.pl; atarn@law.umk.pl

(C) The Author(s) 2018

U. Müßig (ed.), Reconsidering Constitutional Formation II Decisive Constitutional 
of a superior position of constitution towards other sources of law. We may agree as to the purpose of introducing the supremacy clause: first and foremost, it was the desire to guarantee the desired stability of the system against foreign powers' and internal conservative opposition threats. The author developed the title issue in the field of former Polish legal tradition of fundamental law and French influences; analyzed also the extraordinary procedure of adopting and revision of the 3rd May Constitution 1791. Furthermore the perception of the analyzed relationship between the Constitution and acts of ordinary legislation should be regarded as inconsistent. In the following days and months, the deputies of the Great Sejm made attempts to introduce regulations into ordinary legislation that were contrary to the May Constitution, but at the same time the clauses related to the obligation to adjust legislation to the provisions of the Government Act are a much more progressive systemic solution than the previous ones. Contemporary acceptance of the assumption of supremacy of the Constitution leads to the innovative effect of accepting the concept of unconstitutionality, id est the obligation to eliminate from the legal order acts which are incompatible with the Constitution. And again, at the level of the acts comprising the "3 May system" (on the Sejm and the Extraordinary Sejm), this conception remains implemented to a limited degree even when the Sejm deputation was entrusted with the power of preventative constitutional control of draft legislation. It would thus seem that the existing situation can be interpreted as a sort of intermediate stage, symbolizing the arrival of a substantive and axiological legal understanding of the Constitution's supremacy. However, we should objectively assess the innovative Polish steps along the path of encapsulating the state order in a constitutional act, as well as hierarchization of the legal system, however imperfect they may have been.

\section{Introduction}

What is a constitution on the basis of the Stanislawow system of the First Republic? How did contemporaries understand the concept of a superior act? Can the Polish Constitution of 3 May be held up as an example of a modern mechanism serving to enshrine a political system in law? How to avoid the danger of applying present-day institutions to the political and legal practice of the 18th century?

There is no doubt the elite of the First Republic were aware of the fact that the events observed and commented upon in political literature were for contemporaries of an absolutely crucial character. At the same time, all efforts had to be undertaken with the greatest caution, out of fear of the reaction that may come from neighbouring powers, particularly Russia. Even this caution did not, however, prove helpful. "Let it be known to whom it concerns. Overturning the Constitution and the internal Government of the Republic of Poland by illegal revolutions on 3 May 1791. The widespread confusion that continually lasted in this unfortunate epoch in the whole country, and the alarming spread of the spirit of faction and disorder; having enslaved His Royal Highness the King of Prussia, and the Empress of All 
the Russia to agreement and the abolition of the Neighbouring Powers...", was included later in the draft treaty between Russia and Prussia. ${ }^{1}$ Similarly, in private correspondence to "her brother" Stanisław August, Catherine the Great wrote about the "Revolution of the 3rd of May", 2 whereas the subsequent critical Imperial Declaration gives the following account: "the overthrow of the entire Government to its very foundations, on one day of 3 May 1791, under which the Republic has flourished for centuries"3; the process of enacting the Polish Constitution was likened to the French Revolution, and similar public disturbances were expected.

Essen, the ambassador of Saxony, wrote to Dresden "in essence, the total system of governments previously in existence has been overthrown"; "I cannot assess this revolution as anything other than a desperate step, as the nation was convinced of being in danger. I am also certain that this revolution will result in a great deal of problems and difficulties for us". 5

As it turned out, even the limited systemic reform and political revolution which was ultimately carried out, quite mild for the 'truly patriotic' Republican camp, would be too far-reaching of a step. The "revolutionary" argumentation would serve Polish conservatives, enemies of the Constitution: Dyzma Bończa Tomaszewski would write "about the terrible freedom of the Polish revolution" and "the most disastrous revolution". 6 Stanisław Szczęsny Potocki wrote to the king from Vienna in a similar tone: "If I had not seen the King leading the Revolution, I would have perceived it as a plot against the Republic and a blow inflicted to the freedom of the Noble Polish Nation". 7

Polish opinion writing and diplomacy directly countered this. The adoption of the Constitution and accompanying laws was frequently referred to as a "gentle revolution". Hugo Kołłątaj declared "all hope in the gentle revolution, which the

\footnotetext{
${ }^{1}$ 'Niech będzie wiadomo komu należy. Wywrócenie Konstytucyi I Rządu wewnętrznego Rzpltey Polskiey przez nielegalną Rewolucyą 3. Maia 1791. Zamieszanie powszechne, które od tey nieszczęśliwey Epoki w Kraiu całym nieprzestannie trwało, I zatrważaiące szerzenie się w nim ducha fakcyi i zaburzenia; zniewoliwszy Nayiaśnieyszego Króla Imci Pruskiego, I Nayiaśnieyszą Imperatorowę Jeymć Wszech Rossyi do porozumienia się i zniesienia z Sąsiedzkiemi Mocarstwami...', 'Proyekt traktatu Do zawarcia między Nayiaśnieyszym Królem Imcią Pruskim, a Nayiaśnieyszym Królem Imcią I Rzeczypospolitą Polską', Archiwum Głowne Akt Dawnych (Central Archives of Historical Records [further: AGAD]), Archiwum Królestwa Polskiego [further: AKP], Teka 7, Nr 35, k.289-290 (289).

${ }^{2}$ Letter of Catherine, 9 Juillet 1792, AGAD, Zbiór Popielów, sygn. 390, k. 67-69.

${ }^{3}$ AGAD, Archiwum Sejmu Czteroletniego (Four-Years-Seym Archives [further: ASCz]), sygn. 24, k. 81.

${ }^{4}$ Letter of Franciszek Essen to the Minister of Foreign Affairs in Dresden, Johann Loss, of 4 May 1791, No. 21, cited in: Kocój (2000, p. 40).

${ }^{5}$ Letter of Franciszek Essen to the Minister of Foreign Affairs in Dresden, Johann Loss, of 4 May 1791, No. 22, cited in: Kocój (2000, p. 42).

${ }^{6}$ Dyzmy Bończy Tomaszewskiego Komissarza cywilno-wojskowego województwa Bracławskiego nad konstytucyą i rewolucyą dnia 3. maja roku 1791 uwagi, n.p., n.d., f.ex. p. 8-9, 24.

${ }^{7}$ Letter of Stanisław Szczęsny Potocki to Stanisław August, 30 Mai 1791, AGAD, Zbiór Popielów, sygn. 392 , k. 1.
} 
present Parliament should bring us" ${ }^{\prime}$ and the prevalence of the term should be attributed to him, inspired as he was by the ideas of Gaetano Filangieri and Antonio Genovesi. $^{9}$

The term "gentle" was also at the same time to ensure that selecting the path of revolution would be in nobody's interest if identified with the violence of the French Revolution. It is known that in Poland even the organization of the "Black Procession", which was an expression of the demands of the bourgeois, and courageous speeches by representatives of the urban populace, gave rise to an unjustified panic among the noble political nation. Nobody would directly compare the events in Paris and Warsaw; quite the contrary, some luminaries would find numerous differences, ascribing moderation and non-violence to the Polish activities. $^{10}$

In the words of Feliks Oraczewski, deputy of Stanisław August in Paris: "An opinion on freedom has become a Religion, everyone wants to be free but they cannot find the right path. If they are faced with the smallest obstruction, they will turn violent against the people". ${ }^{11}$ In a letter to an unknown addressee written much earlier, Oraczewski argued naively that "we do not know what the reception of Our Revolution was in Vienna, Berlin or St. Petersburg, but it can be inferred from Bulgakov's countenance and demeanour that Moscow will not wage a war on us for the Revolution, just as it did not wage a war on the King of Sweden 19 years ago". 12 Already in 1789 after first reform of Great Sejm, as for example military organisation reform, the Marshal of the Lithuanian Confederation appealed to the king in these words: "Our revolution is different from that in other Countries, for there the peace has been broken, and the result was the destruction of all the impulse to revolution; everything was done here in an undisturbed peace, and in this Sejm where we make law, its Performance is to be found. The Deputation made to

\footnotetext{
${ }^{8}$ Kołłątaj Hugo, Do Stanisława Małachowskiego, referendarza koronnego. O przyszłym sejmie Anonima listów kilka, cz. 1: O podźwignięciu sił krajowych, List Pierwszy, Biblioteka Polskiej Akademii Nauk w Krakowie, Rkp. (manuscript) 176, k. (charter) 6.

${ }^{9}$ Leśnodorski (1975).

${ }^{10}$ About this "tactical" issue cf. also Salmonowicz (2001).

${ }^{11}$ ،opinia o wolności stała stała się Religią, wszyscy chcą być wolnemi ale porządnie trafić na tę drogę nie umieią gdy się naymnieysza pokaże zawada gwałtem prze-ciw ludowi czynią', letter of Feliks Oraczewski to Stanisław August, AGAD, Zbiór Popielów, sygn. 418, k. 295.

${ }^{12}$ ‘Jeszcze tu nie wiemy, iak Nasza Rewolucya iest wzięta w Wiedniu, Berlinie y Petersburgu, lecz po minie i zachowaniu się Bułhakowa można suponować, że Moskwa nam nie wypowie woyny za Rewolucyę, iak niewypowiedziała przed lat 19 Królowi Szwedzkiemu', Letter of Feliks Oraczewski to NN, w Warszawie, dnia 11 Maja 1791, AGAD, Zbiór Popielów (collection of Popiel family), sygn. 418, k. 571. Jakov Bulgakov was Russian envoy in Warsaw 1790-1792, successor of Magnus Otto Stackelberg (in Warsaw during 1772-1790).
} 
compose the form of the Government has crowned the anniversary of the Election of Your Royal Highness". 13

Even as the Russian declaration ${ }^{14}$ opening the way to Russian-Polish war was published, the aforementioned royal deputy deluded himself further with the following words: "I think that the proclamation requires a genuine explanation which would distinguish our revolution from the French one and prove the proclamation of St. Petersburg erroneous". 15 After publishing the Russian declaration in Paris, Oraczewski called for a widespread explanation of how much the Polish reform, which was curbed by religion and the "simplicity of customs", was divergent from the French Revolution. ${ }^{16}$ He sees the mechanisms that will effectively protect the Constitution in the very same traits and in the leadership of the king. Besides, the Constitution "does not need any protection as it will defend itself in the eyes of the People of Europe". 17

Oraczewski, as well as many others, demonstrated extreme naivety. The Russian narrative was of a strictly propagandistic character. On the one hand, to satisfy the demands of international diplomacy it referred to the theoretical danger posed by the spread of revolutionary ideas; on the other, it sought to protect Polish liberty "threatened" by the constitution. In response to the charge that this was an odd argument coming from a state which itself was of a despotic nature, the Russian ambassador Bulgakov was said to have responded to Marshal Kazimierz Sapieha that in Russia this had been the case for a long time, but "... your despotism began on Monday, 16 April (...) You issued a declaration of war against all of Europe, and specifically against us". Sapieha responded that "it is entirely something other than despotism, that which we have done solely in our own defense (...) The entire nation has verified and consecrated the act of 3 May. And whatever we may do now, we do

\footnotetext{
${ }^{13}$ Rewolucya [s. 333] Nasza różna iest od rewolucyi innych Kraiów, bo tam zamięszani spokoyność, i obalone wszystkie sprężyny rewolucyi były skutkiem, u Nas w nienaruszoney spokoyności wszystko się stało, i w tym Seymie, w którym stanowiemy Prawa, znayduie się ich Exekucya. Deputacya wyznaczona do układania formy Rządu uwieńczyła rocznicę Elekcyi W. K. Mci' Sessya 195, 24th November 1789, Diariusz Sejmu Czteroletniego (sessions 98-198 and 327), from the manuscript preserved in AGAD, http://www.wbc.poznan.pl/dlibra/publication?id= 20152\&tab=3 (2016-10-03).

${ }^{14}$ AGAD, AKP, Teka 1, Deklaracja of 8th/18th May 1792. Comments of the King in his letter to Deboli, 19th May 1792, AGAD, Zbiór Popielów, sygn. 413, k. 381-382.

${ }^{15}$ 'zdaje mi się, że ta proclamacia potrzebowałaby objaśnienia autentycznego które by pokazało różność celu y przyczyn rewolucyi naszey od Francuskiei y omył-kę proklamacyi Petersburskiej', letter of Feliks Oraczewski to the King, 9th March 1792 Paris, AGAD, Zbiór Popielów, sygn. 418, k. 277.

${ }^{16}$ Letter of Feliks Oraczewski to the King, 5th March 1792, Paris, Zbiór Popielów, sygn. 418, k. 270-273.

17،nieobrażaiąc nikogo sama się lepiey broni w opinii powszechności całey Europy', letter of Feliks Oraczewski to the King, 18th May 1792, Paris, AGAD, Zbiór Popielów, sygn. 418, k. 365. Cf. also elaboration of the correspondence: Kocój (1988).
} 
as a free Nation, which desires not to attack, but only to defend itself'. ${ }^{18}$ His riposte, however, was in vain. Yet another element of the anti-constitutional narrative consisted in highlighting the fact that the new acts were a breach of the existing law and the guarantees given under Russian pressure of $1775-1776^{19}$ (the notes of Stackelberg, and his successor Bulgakov's Declaration). Ambassador of Stanisław August, Antoni Augustyn Deboli was more aware of these facts and had prophetically wrote to the King, in the beginning of 1792, in relation to the meetings of the Dietines which were about to be held in February and were supposed to give an opinion on the Constitution Act: "I always say that Your Majesty and everyone else has to devote to the success of the meetings of the Dietines and to demonstrate patriotism, not to overthrow the Constitution. Otherwise, the latter will result in the partition of Poland, since rumours could already be heard that each of the three Powers would take a part of Poland, and the rest would be turned into the Duchy to be given to a few, under obeisance respectivé of these Powers". ${ }^{20}$

Jörg K. Hoensch called the Empress' manifesto of May 1792 "grandiose Machiavellianism in its political insincerity and unscrupulousness. The woman of the Enlightenment, a supporter of liberty and natural rights and a correspondent of Voltaire, Grimm, Falconet, and d'Alembert, denied the Polish nation its freedom to establish a constitution for itself and took refuge in the state guarantee of 1768. The autocrat criticized the "despotism" of the new hereditary monarchy and simultaneously its democratic elements". ${ }^{21}$

This particular issue - awareness of essential reforms, the drive to retain external sovereignty, and to strengthen structures of the state while permanently in a state of fear regarding the reaction of Russia - can potentially explain the extreme inconsistency in the actions taken by the Constitution's framers, and perhaps even understand its essence. As early as in the first months of the Great Sejm, Essen had already began to operate under the assumption that the fate of Poland would be decided in Berlin and Petersburg. ${ }^{22}$ The mere expression "gentle revolution" would seem to be a symbolic reflection of the paradoxes associated with the preceding. ${ }^{23}$

\footnotetext{
${ }^{18}$ Sapieha: 'wcale iest różnym od despotyzmu, cośmy tego dnia iedynie dla obrony naszej uczynili (...) Cały naród potwierdził y poświęcił czyn 3 maja. A cokolwiek teraz czyniemy, czyniemy iako Naród wolny, który nie atakować, ale tylko bronić Siebie chce', relation in the letter of the King to Deboli, No 120, 28 Aprilis 1792, AGAD, Zbiór Popielów, sygn. 413, pp. 369-370.

${ }^{19}$ AGAD, Archiwum Publiczne Potockich [further: APP], sygn. 97, p. 49.

${ }^{20}$,ja zawsze powiadam, że gdy się wszyscy wraz z Waszą Kr. Mością nie przyłożą do sukcesu tych Sejmików, y do okazania patriotyzmu, nie na wywrocie Konstytucyi skończy się, ale na dziale Polski, bo iuż znowu daią się słyszeć odgłosy o tym zamyśle, to iest: że każda z trzech Potencji weźmie część Polski, a resztę obrucą (sic) w udzielne Księstwo dla kilku osób pod hołdownictwem respectivé tychże Potencyi". Letter of Antoni Augustyn Deboli to the King, $\mathrm{Nr}$ 83, ce 6./ce 17. Janvier 1792, AGAD, Zbiór Popielów, sygn. 415, pp. 8v-9.

${ }^{21}$ Hoensch (1997, p. 442).

${ }^{22}$ Kocój (1996, pp. 32, 87).

${ }^{23}$ Cf. analysis of Pepłowski (1961, pp. 53-59).
} 
An analysis of the issue presented in the title of the work, that is of the precedence of the constitution on grounds of Polish constitutional activities taken in 1788-1792, should begin with several remarks of a definitional nature, and then be followed with a brief description of the sources used. The substantive chapters will be devoted to the extraordinary procedure applied in adopting the Government Act, the Polish tradition of the Henrician Articles and Pacta Conventa, the issue of the relation between the Government Act and the Cardinal Laws, and finally the nullification clause and relation of the Government Act's provisions to the normal legislation of the Great Sejm.

\section{A Note on Terminology}

Implementation of the principle of constitutional supremacy in constitutional practice allows for the possible existence of lower-level laws whose compliance with the constitution, when controlled, will be called into doubt. However, before it becomes possible to speak more broadly about the problem of actions contrary to the Constitution, it should be noted what terminology was used in the era being discussed. Importantly, it was common in the era of the Great Sejm to be aware that thorough political and systemic reforms were required, which were to bring a "new form of government".

This concept was anchored in opinion journalism: for example, one anonymous author gave his work the title "Thoughts on Improving the Form of Government", and published it in the "Collection of Works Inspired by Observations on the Life of Zamoyski". ${ }^{24}$ Another anonymous author of a comprehensive work entitled "On the Law and Duties of Citizens" stressed the right of every citizen to demand the establishment of a "form of government", which would "bring about common happiness". 25 This term was used also when appointing the confederated Sejm and stating that its task would be to enact a Form of Government. ${ }^{26}$ In mid-September 1789 a parliamentary deputation was chosen and tasked with "preparing Drafts for the Form of the Government". ${ }^{27}$ Similarly, the recommendations adopted in December 1789 bore the title "Principles for Improving the Form of Government", 28

\footnotetext{
${ }^{24}$ Zbiór Pism, do których były powodem Uwagi nad życiem Zamoyskiego. Osme pismo. Myśl względem poprawy Formy Rządu, Roku 1790 (Collection of writings, which were the reason Observations on the life of Zamoyski. Eight Scripture. A Thought for Improving the Form of Government, 1790).

${ }^{25} \mathrm{NN}$, O prawie i powinnościach obywatela, w Warszawie, u p. Dufour Konsyl. Nadwor. JK.Mci Dyrektora Druk. Korp. Kad. MDCCXCI [1791], p. 21.

${ }^{26}$ Uniwersał, AGAD, AKP, Teka 7, Nr 10.

${ }^{27}$ Sessya Seymowa 155, 14 września 1789, electronic version transcribed by Biblioteka Kórnicka: http://www.wbc.poznan.pl/dlibra/publication?id=20152\&tab=3 (2016-10-03).

${ }^{28}$ Zasady do poprawy formy rządu, Volumina Legum, Wydawnictwo Komisyi Prawniczej Akademii Umiejętności w Krakowie, t. IX, Kraków 1889, pp. 157-159.
} 
and the comprehensive draft constitutional law of August 1790 was a "Draft for the Form of Government". The King wrote in his letters to Deboli about "Government reform". We should clarify here that in those times the concept of government implied a political system, and should not be identified solely with the executive power but rather the entire model of governments.

In addition, the term "constitution" has been used both in the subject literature and legislative work. It should be recalled that originally the ordinary legislation adopted by the Sejm was in the form of acts called constitutions, from the time "when estates entered into a legislative commune with the king," i.e. in practice from $1510 .{ }^{29}$ The author of the aforementioned Eighth Scripture referred as early as in 1790 to the "constitution" in the specific sense as "all the rights which universally constitute the security of liberty, property, honour and life of every citizen in particular, the change of which rights may only be to the detriment of another, they are the rights that define estates, sovereignty, gravity, offices, and their competences, the description of which makes up the fundamental Constitution of the Government". 30 The concept of the constitution was sometimes thus identified with the organization, the totality of the political system, as in the case of Franciszek Salezy Jezierski: "The freedom of the nation thrives in the Constitution of the Government, and not in the choice of the Ruler, the power of the king set out in judicious laws, the Rights of Man reserved in their entirety, the law-making power placed in the hands of the States composing the Nation, the Executive power entrusted to magistrates by the selected States, the composition is true freedom, the rest is merely a vacuous conceit that a riotous unitary authority can use to entice, and attempt to retain others in bondage". ${ }^{31}$ Kołłątaj wrote in similar tones of the "Constitution of the Government", with such recommendations as "The lawmaker,

\footnotetext{
${ }^{29} \mathrm{Cf}$. „konstytucye”, Zbior potrzebnieyszych wiadomości porządkiem alfabetu ułożonych, Vol. II, Za przywilejem w Warszawie i Lwowie 1781, Nakładem i Drukiem Michała Grölla, Księgarza Nadwornego J.K. Mci w Marywilu pod Nro 24, p. 473.

${ }^{30}$ te wszystkie prawa, które w powszechności stanowią bezpieczeństwo wolności, majątku, honoru i życia każdego w szczególności Obywatela, których odmiany nie może zyskać jedna osoba, tylko z pokrzywdzeniem drugiej; to iest, które opi-suią stany, moc, powagę, urzędy, i onych władzę, a tym opisem urządzają istotną fundamentalną Konstytucyą Rządu', Zbiór Pism, do których były powodem Uwagi nad życiem Zamoyskiego. Osme pismo..., p. 37.

${ }^{31}$ 'Wolność narodu zasadza się na Konstytucyi Rządu, nie na wyborze Osoby do Panowania, władza króla rozsądnemi opisana prawami, Prawa Człowieka zawarowane w całej swej zupełności, Władza prawodawcza złożona w ręku Stanów Naród składających, władza Wykonawcza powierzona magistratom przez Stany wybranym, składem iest prawdziwey wolności, reszta iest tylko próżnym ułudzeniem, którym rozchukane (sic) możnowładztwo siebie mamić, a innych w niewoli trzymać usiłuie', NN (Jezierski, Franciszek Salezy), O Bez-Królewiach w Polszcze y wybieraniu krolow począwszy od śmierci Zygmunta Augusta Jagiełły aż do Naszych czasów. Dzieło w teraźnieyszych okolicznościach do wiadomości przydatne, w Warszawie 1790 Roku (On interregnum times in Poland and the election of kings from the death of Sigismund Augustus Jagieło until our times. A useful work in the present circumstances, in Warsaw, 1790), p. 8.
} 
I do say, should first determine for itself why this new Constitution is of necessity for the Nation". 32

One of the deputies wrote about adopting of "Government Law and the Government itself, because it is not the temporary but the permanent, stable and non-changeable existence of Constitution and the Government in its comprehensive meaning what creates the political presence of each Nation, what gives it respect and puts it in a number of reputable powers". 33

Particular undisclosed revisions of the final phase of draft legislative works bore the titles "Reform of the Constitution", 34 "Constitutional Rights"35 and "Political Constitution of the Polish Nation". 36 The very term "constitution" is not included in the title of the Act of 3 May 1791. It was given the name "Government Act" to distinguish it from ordinary parliamentary legislation. "Government" in this case means the same as "systemic".

A certain inconsistency should be noted: the intention of the lawmaker is "to further the establishment and the perfection of the National Constitution", which should be interpreted broadly as a synonym for the totality of political and legal relations within the political system. In further fragments, however, direct reference is made to the Constitution and the Act of 3 May. However, in the introduction it is said that "further acts of the present Sejm ... should all adhere to the Constitution" (this will be discussed in greater detail later); additionally, in the Declaration of the Assembled Estates of 5 May 1791, ${ }^{38}$ which is a key legislative act in this discussion, the term "constitution" was used. In practice, moreover, the term "Government Act" was not widely accepted (although the parliamentary

\footnotetext{
32، Prawodawca, mówię, powinien nayprzód rozebrać sam u siebie, dla to czego nowej Konstytucyi Narodowi potrzeba?', NN (Kołłątaj, Hugon), Krotka rada względem napisania dobrey Konstytucyi Rządu, n.p., Roku 1790 (Some advice on composing a good Constitution of the Government in 1790), p. 6, p. 20. Kołłątaj also uses the phrase "Form of the Government" as an equivalent.

${ }^{33}$ 'Rządowey Ustawy, i samego Rządu, bo to co polityczną każdego Narodu ustanawia bytność, co szanownieysze onego czyni znaczenie, co go w rzędzie poważanych umieszcza Mocarstw, iest to nie czasowa, lecz trwała, pewna i nieodmienna Konstytucyi rządowey exystencya, iest Rząd w całym słowa tego wzięty znaczeniu', Głos Michała Odrowąża Strasza posła województwa sandomierskiego Dnia 20. Marca 1792 R. Na Sessyi Seymowey Miany (Voice of Michał Odrowąż Strasz, deputy of Sandomierz Voivodship). AGAD, ASCz, sygn. 24, k. 231.

${ }^{34}$ Draft written by Aleksander Linowski dictated by the king. The draft was translation of „Projet de réforme de Constitution”, fair copy prepared by Scipione Piattoli. AGAD, APP sygn. 98, pp. 733-755.

${ }^{35}$ Text written by Hugo Kołłątaj, based on „Reforma konstytucyjna”.

${ }^{36}$ Text of Hugo Kołłątaj: „Prawa ostatecznie podane, które mają składać I Rozdział Konstytucji Politycznej Narodu Polskiego", dnia 25 marca 1791 r., Ossolineum Zakład Narodowy im. Ossolińskich we Wrocławiu, rkp. 1778, Zbiór pism rozmaitych z czasów sejmu konstytucyjnego (Czteroletniego) od roku 1788 do 1792, pp. 201-233.

${ }^{37}$ Normal, usual acts of the Sejm were referred to using the word constitutio, in the Roman tradition. Cf. remarks by Grodziski (1983). On catalogue of legal sources in Sejm legislation: Kucharski (2012, pp. 127-159).

${ }^{38}$ Deklaracya stanów zgromadzonych, Volumina Legum, Wydawnictwo Komisyi Prawniczej Akademii Umiejętności w Krakowie, Vol. IX, Kraków 1889, pp. 225-226.
} 
debate saw the use of the phrase "the sacrosanct Act",39); it was basically referred to as the Constitution, and henceforth ordinary legislation was referred to as the "law". 40 A "constitutional parliament" was also one of the names invoked. In his correspondence (such as with Deboli) the king used the phrases "Constitution of 3 May" and "revolution of 3 May" interchangeably.

Subsequent legislative acts of the Polish state already referred directly to the term "Constitution" (Constitution of the Duchy of Warsaw 1807, ${ }^{41}$ and the Constitutional Act of the Polish Kingdom $1815^{42}$ ).

\section{Characteristic of the Sources}

ReConFort employs a particular scope of selection of sources. Of course, in the first place it goes for traditional juridical materials, id est for the purposes of this work published diaries of the Sejm were investigated, ${ }^{43}$ as well as a partially handwritten manuscript detailing the activities, Minutes of the Sejm. ${ }^{44}$ They are complimented by prints of speeches by the king, senators and deputies of the Sejm. That category of sources also includes products of the Sejm's lawmaking process, drafts and adopted acts published as collections of Sejm constitutions, a range of prints based on oblate (Pol. oblata, registration in borough books), and also edited in 19 ct. collection of law, called Volumina Legum, Vol. IX. ${ }^{45}$

ReConFort also makes use of a broad range of media. It can be characterized by referring to the determinations in ReConFort $\mathrm{I},{ }^{46}$ as well as the relevant subject

\footnotetext{
${ }^{39}$ For example: Sessya Seymowa 83. Dnia 30. Maja 1791, AGAD, ASCz, sygn. 19, k. 367.

${ }^{40}$ Bardach (2001, pp. 16-17).

${ }^{41}$ Konstytucja Księstwa Warszawskiego Z 22 lipca 1807 r. (Dziennik Praw [Księstwa Warszawskiego] 1807 r., t. I, s. II-XLVIII) (French: Statut Constitutionnel du Duché de Varsovie, Le Moniteur Universel No 214, Dimanche, 2 Aoŭt 1807).

${ }^{42}$ Polish Constitutional Act of the Kingdom of 15/27 November 1815 (French: Charte Constitutionelle du Royaume de Pologne). Rumours about the reinstatement of the May Constitution and such a will signalled by the Dietines in the period after Napoleon's fall in 1812 should be noted: Rosner (1998, p. 33).

${ }^{43}$ Dyaryusz seymu ordynaryinego pod związkiem Konfederacyi Generalney Oboyga Narodow w Warszawie rozpoczętego roku... 1788/[wyd. Jan Paweł Łuszczewski] Diariusz Sejmowy - 17881789 Drukarnia Nadworna, Warszawa w Warszawie: w drukarni Nadwornej J.K.Mci i... Kommissyi Eduk[acyi] Narodowej [po 3 XI 1788]-1790, Dyaryusz seymu ordynaryjnego pod związkiem Konfederacyi Generalney Oboyga Narodow w podwoynym posłow składzie zgromadzonego w Warszawie od dnia 16 grudnia 1790/[wyd. Antoni Siarczyński], w drukarni... Michała Grölla... [1791].

${ }^{44}$ Dziennik Czynności Seymu Głównego Ordynaryinego Warszawskiego pod związkiem Konfederacji Oboyga Narodów agitującego się, partly printed, partly manuscripts: AGAD, ASCz.

${ }^{45}$ Volumina Legum, Wydawnictwo Komisyi Prawniczej Akademii Umiejętności w Krakowie, Vol. IX, Kraków 1889.

${ }^{46}$ Müßig (2016).
} 
literature. ${ }^{47}$ However, neither on the pages of "Gazeta Narodowa Y Obca" nor "Pamiętnik Historyczno-Polityczny Przypadków, Ustaw, Osób, Miejsc i Pism wiek nasz szczególnie interesujacych" will the reader encounter a discussion of the legal character of the Government Act, which is why this category of sources constitutes a less important source of material for deliberation.

The category of media under discussion also includes free writings. The phenomenon of their popularity in the 1780s and 1790s has been accented by the author in ReConFort I. As an aside, mention can also be made of the so-called "militant literature", 48 serving as a sort of complement to the free printings. Works classifiable as fiction and theatre pieces played a not insignificant role in transforming public opinion. The fear felt by conservatives towards this process is illustrated inter alia by the fact that the Marshals of the confederation were summoned by the deputy Suchorzewski to convene the Sejm Courts. Before that court Suchorzewski brought charges against the police for permitting the J.U. Niemcewicz comedy "Return of the Deputy" to be performed, in which there is mention of introducing succession to the throne, formally forbidden under Pacta Conventa. While the king described events as amusing, he did express his disquiet that the obstinacy of Suchorzewski in such absurdities would lead to a multiplication of "the number of hindrances to things more helpful", which should most certainly be understood as concern over a potential shift in the general mood problematic for the planned reforms. ${ }^{49}$ The King was forced to defend the comedy itself and its anti-Petersburg tenor before Bulgakov. ${ }^{50}$

It is mass literature that played an incontrovertible role in the evolution of political leanings and worldview in society at large, although the opinion expressed by the King to Maurice Glayre may be somewhat overblown: "We were a nation of badly raised children, mouthy and wanton, alternatively timid and courageous through ignorance or carelessness, and we remained fast in our prejudices. All this has passed." 51

ReConFort also proposes analysing the private correspondence of the protagonists as sources for recreating the constitutional debate, offering the potential to reach additional and sometimes unexpected conclusions from the legal history perspective. In the Polish case, where one of the key actors is the monarch, letters of a quasi-official status frequently are of greater value, such as correspondence with Antoni Augustyn Deboli, the 'plenipotentiary minister' to Petersburg, or with Feliks Oraczewski, emissary in Paris. However, analysed correspondence is essentially private, in which diplomatic considerations are accompanied by expressions of the king's sympathies and fears; he describes events from sessions of the Sejm, repeats rumours about the foreign mistresses of politicians, and relates his conversations with antagonists. Deboli supposedly did not hesitate to remonstrate with the king and instruct him in various matters; the King, for his part, only presented the letters to

\footnotetext{
${ }^{47}$ Lojek (1960, pp. 49-192).

${ }^{48}$ Woźnowski (1971).

${ }^{49}$ Letter to Deboli, January 19th, 1791, AGAD, Zbiór Popielów, sygn. 413, k. 14.

${ }^{50}$ Letter to Deboli, January 22nd, 1791, AGAD, Zbiór Popielów, sygn. 413, k. 15-16.

${ }^{51}$ Mottaz (1897, p. 252). Citation translated in Polish: Dembiński (1904, p.3.)
} 
officials of the Warsaw court after creating censored copies of them, concealing their overly informal elements. ${ }^{52}$ Portions of the correspondence of key protagonists were collected (including editions of Stanisław Dembiński, Bronisław Zaleski, Henryk Kocój, Maria Rymszyna and Andrzej Zahorski). An in-depth analysis, however, requires a very extensive query, ${ }^{53}$ which has so far only been conducted partially. The author also makes use of valuable subject literature.

\section{French Inspirations of Polish Republicans: Drafts of Mably and Rousseau}

A complimentary thread alongside the primary deliberations is the issue of foreign influences on the political and systemic thought accompanying the reforms of the Great Sejm. This is an issue which has been raised multiple times and is well-described in the subject literature, if not somewhat less visible in the Western literature. It cannot be discussed in great detail here, which is why I would like to refer only to the republican strand of thought, represented by two theoreticians and writers in French: Father Gabriel Bonnoit de Mably and Jean-Jacques Rousseau, as those who, somewhat earlier in the 1770s, prepared draft reforms of the Polish state, on request of the confederates of Bar. ${ }^{54}$

The primary problem in Western analyses of Polish issues of the time is indirect access to sources. On the one hand, Polish was not a familiar language; on the other, there were few willing to engage in the risky journey to the distant east. Out of necessity Western authors based their writings on stories from governors employed in Poland or the journals of travelers, ${ }^{55}$ with the errors and oversights contained in them. One example is the picture painted of Poland in Diderot's Encyclopaedia under the entry "Pologne, histoire et gouvernement de (Histoire et Droit politique)", composed by Louis Chevalier de Jaucourt, or "Droit de Pologne" by Antoine Gaspard Boucher d'Argis. Similar entries by that author were prepared with far more diligence than those concerning Poland. ${ }^{56}$ It was not until the 1770

\footnotetext{
${ }^{52}$ This went both ways - the King also hid various facts from Deboli. Łojek (1964, pp. 17-18).

${ }^{53}$ Especially in AGAD - APP, Zbiór Popielów; also Biblioteka Książąt Czartoryskich (Czartoryskis Library, royal correspondence).

${ }^{54}$ Bar Confederation (konfederacja barska) - an armed association of Polish patriotic-conservative nobility formed in Bar in Podolia, directed against the Russian-imposed King Stanisław August and the cardinal laws passed by the guardianship of the Russian Empire in February 1768. The Confederation, supported by France and Turkey, it summoned the uprising led by, among others, the young Kazimierz Pułaski. The last flames of revolt flickered out in Summer and Autumn of 1772 (Tyniec, Wawel, Jasna Góra), while the Confederation itself served as one of the pretexts to the first partition of Poland conducted that year by Russia, Austria and Prussia.

${ }^{55}$ Zawadzki (1963), Figeac (2014), Jakuboszczak and Sajkowski (2014).

${ }^{56}$ Wolodkiewicz (1996).
} 
1779 Livorno printing of the Encyclopaedia that it contained a correction with a much more accurate description of the legal system in Poland. ${ }^{57}$

It should be recalled that in the 1760s, a French governor in the Sanguszko family, César-Félicitas Pyrrhis de Varille, published his work "Compendium politicum...", 58 which was strongly influenced by Rosseau's earlier writings while at the same time containing ideas similar to those which would appear soon thereafter in "Considerations on the Government of Poland", and which might have served as inspiration for the Genevan citizen. Slightly later, in 1769 Pyrrhis de Varille announced the "Lettres sur la constitution actuelle de la Pologne et la tenue de ses diétes" ${ }^{59}$ in which he also took up the issue of political reforms, drawing attention to similar elements that Rousseau would soon explore-reorganization of the Sejm (eliminating the liberum veto in favour of a minority vote in cardinal cases), reform of the assemblies, criticism of the interregnum and expression of concern over foreign intervention. In acknowledgement of Pyrrhis de Varille's writings, in 1764 the Sejm granted him indygenat (naturalization for a foreign nobleman).

Rousseau's writings quickly made their way to Poland, where they were employed in public oration without indicating their author. ${ }^{60}$ "Considerations on the Polish government" 61 came about as a result of a short-lived intimacy with

\footnotetext{
${ }^{57}$ Encyclopédie, ou... Troisiéme édition enrichie de plusieurs notes, Dédidée à son Altesse Royale Monsigneur l'Archiduc Pierre Léopold Prince Royal de Hongrie et de Bohême, Archiduc d'Austriche, Grand Duc de Toscane etc. etc., Vol. I-17, a Livourne 1770-1778. Note on Polish law system was published in Vol. 5, pp. 150-151.

${ }^{58}$ Pyrrhis de Varille, Compendium politicum seu brevis dissertatio de variis Poloni Imperii vicibus in qua Reipublicae sive Libertatis, necnon in Comitiis Vetandi Juris Origo, Progressus et Status praesens nova methodo inquiruntur, 1761, Polish translation, "Zebranie polityczne", published two years later.

${ }^{59}$ à Varsovie et se trouve à Paris chez Gaugery, $8^{\circ}$. Letters sent officially to the pupil, Prince Jan Sanguszko, circulated already in the country in copies Szyjkowski (1913, p. 53).

${ }^{60}$ Speech of X. Szymon Wyhowski, September 1778. Cf. Szyjkowski (1913, pp. 21-22). Supposedly, Karol Wyrwicz, rector of the Jesuit college in Warsaw, in his introduction to "A geography of current times" (1770) and then "A history of ancient states" plagiarized Montesquieu's "Spirit of the laws". He also did not hesitate to present the paper as an original at 'Thursday dinners' (meetings of artists, intellectuals, architects and politicians held by Stanisław August. Smoleński (1927, pp. 64-69). Fragments of the "Social contract" of Rousseau appeared in Polish in the form of an anonymously-published brochure „O wolności człowieka”. Szyjkowski (1913, pp. 37-38).

${ }^{61}$ Considerations sur le gouvernement de la Pologne et sur sa reformation projetée, original in Biblioteka Czartoryskich, 1st ed. London 1782. For this elaboration has been used: [Rousseau, J. J.], Uwagi nad rządem polskim oraz nad Odmianą, czyli Reformą onego projektowaną przez J. Jakuba Russo obywatela genewskiego z Francuzkiego na Oyczysty ięzyk przełożone Miesiąca Grudnia dnia 20. R. 1799. Część I-Część II, w Warszawie, 1789, Nakładem i Drukiem Michała Grölla, Księgarza Nadwornego J.K. Mci. The translator in Polish was an apologist of Rousseau, Maurycy Franciszek Karp.
} 
Michał Wielhorski and on the basis of his "Picture of the Polish government". 62 In Chapter V, Rousseau called for a reinvigoration of the Polish Government, “... granting a Constitution to the great Kingdom, a constancy and energy to the Republic". ${ }^{63}$ He felt that his original ideas on decentralization (separation into equal provinces a "division into two Polands, as well as Lithuainias", as many "states as provinces", each with "its own governments", strengthening of the authority of assemblies) were consistent with the "spirit" of the Polish constitution. ${ }^{64}$

The existing Polish legislation he describes to be "comprised over time out of bits and pieces", as all European laws. ${ }^{65}$ The point of departure is the concept of the sovereignty based on the knighthood. It was supposed to slowly transform into a true nation, followed by the emancipation of the non-noble classes, very conservative in relation to the peasantry (which long supplied arguments to opponents of peasantry reforms), through their inclusion into a system of a public judiciary, or enfranchisement upon the application of special censor commissions, Comités censoriaux. ${ }^{66}$ The philosopher appealed for the retention of the binding nature of Sejm instructions (a Sejm entirely dependent on the assemblies), and even expressed regret that similar institutional "curbs" available to Sejm deputies were not present in the British model. ${ }^{67}$ Deputies (or potentially assemblies, the Dietines) should also elect senators, yet it should be noted that the arguments presented by the Genevan here were somewhat inconsistent. He declared the head of state to be a "natural enemy of liberty", and in reference to the replacement of the elected monarch with a hereditary one, he said that Poland could "forever say goodbye to its freedom". 68 In the interregnum he saw the moment when the Nation restored its rights, and legislation recovered its resilience. In Rousseau's opinion, weakening of the royal privileges could make the monarch the "first Citizen". This alone demonstrates that the Genevan was provided with biased information about the Polish system, with its ineffective executive. ${ }^{69}$ The actual weakness of the state and debauchery associated with the interregnum was one of the often-raised arguments in favour of a hereditary throne. Another entirely original idea, and one unacceptable in light of the Polish tradition of

\footnotetext{
${ }^{62}$ This picture, according to Szyjkowski, was the work of Wielhorski „O przywróceniu dawnego rządu według pierwiastkowych Rzplitej ustaw”, 1775. Szyjkowski (1913, p. 71). Jerzy Michalski, however, later identified it with an entirely different treatise by Wielhorski, written specially for Rousseau, which he referred to as Tableau. Michalski (1977, pp. 11-12). Work of Michalski has also been also translated in English: Rousseau and Polish republicanism, Warszawa 2015; http:// rcin.org.pl/Content/58076/WA303_78371_JM_Michalski-eng.pdf.

${ }^{63}$ „dania Konstytucyi wielkiemu Królestwu, trwałości i rzeźwości małym Rzeczom-pospolitym własney", [Rousseau, J.J.], Uwagi..., p. 41.

${ }^{64}$ [Rousseau, J.J.], Uwagi..., pp. 43-44.

${ }^{65}$ [Rousseau, J.J.], Uwagi..., p. 51.

${ }^{66}$ Michalski (1977, pp. 37-44).

${ }^{67}$ [Rousseau, J.J.], Uwagi..., p. 61. On the Sejm and assemblies see also: Michalski (1977, pp. 4558).

${ }^{68}$ [Rousseau, J.J.], Uwagi..., pp. 82, 87.

${ }^{69}$ Analysis of recommendations for legislative power: Michalski (1977, pp. 92-106).
} 
the theoretical equality of the nobility, was the building of a separate class, ,membres actifs de la République", a sort of elective "aristocratic government", based on people with experience holding state office, who would therefore be entitled to campaign for successive functions. Paradoxically, he was also an opponent of professionalization of the state apparatus, and the aforementioned careers were supposed to be based on the trust of fellow citizens, demonstrating a sort of virtue - a similar concept worked its way into the project Rousseau prepared for Corsica. ${ }^{70}$

Among divagations on the model of the state there are general indications that the law should be a collection of simple and clear rules that members of society should know and respect. ${ }^{71}$ Rousseau criticised expansive and complex codifications based on the Roman law - "this was harmonious with opinions firmly rooted in Polish noble society, wary of the Roman law and professional lawyering, but practically familiar with the law, respecting the civil model of offices and courts". ${ }^{72}$ There is an absence of reflection on the potential specific role of the Constitution, considering that Rousseau writes of the "act, that is, a Constitution". He also essentially calls into question the concept of fundamental laws ("a gaggle of articles which have been absurdly counted among the fundamental laws, and which are but a mere collection of legislation ..."73). He thus treats the Constitution substantively, as a collection of key laws regulating the political organization of the state, and also economic and military matters. ${ }^{74}$ In the philosopher's opinion, the nation has the right to "amend" and "refresh" its constitution, ${ }^{75}$ yet the deepening anarchy in the state meant that the solutions offered by Rousseau gave no guarantee of success. ${ }^{76}$

Already in the 18th century we may encounter the opinion that certain elements of "Considerations" (Considérations) are incompatible with conceptions of Rousseau's in "The Social Contract" (e.g. the relativizing concept of the nation, or enthusiastic praise for anarchical confederations), and that it was an example of advice tailored to the specificities of the subject matter. A different opinion is held by Jerzy Michalski, who does not perceive such contradictions, and even declares that Considérations complement and extend Rousseau's doctrine as known from

\footnotetext{
${ }^{70}$ Michalski (1977, pp. 99-101).

${ }^{71}$ In notes of Rousseau, Michalski (1977, p. 101).

${ }^{72}$ [Rousseau, J.J.], Uwagi..., p. 102.

${ }^{73}$ 'mnóstwo artykułów, które śmiesznie w liczbę praw fundamentalnych pokładano i które iedynie zbiór prawodawstwa składają...', [Rousseau, J.J.], Uwagi..., p. 99.

${ }^{74}$ In respect of the organization of the armed forces, he wrote: "Poles! You should not look around and seek to emulate even that which they (neighbouring monarchies) are doing properly. These remedies applied to constitutions of such disparities would be an evil in their Constitution" („Polacy, nie powinniście się zapatrować dokoła siebie, chcąc nawet tego naśladować, co się u nich [sąsiednich mocarstw] dobrze dzieje. Ta dobroć stosowna do Konstytucyi cale się różniących, byłaby złem w ich Konstytucyi”), and he encourages the formation of a militia in the Swiss mold. [Rousseau, J.J.], Uwagi...p. 130.

${ }^{75}$ [Rousseau, J.J.], Uwagi..., p. 178.

${ }^{76} \mathrm{~A}$ broader comparative analysis of Rousseau's work (based on the French original) $i$ Wielhorskiego cf. Szyjkowski (1913, pp. 75-101); on Tableau also Michalski (1977, pp. 18-26).
} 
other works. However, they retain a rather literary-rhetorical form, replete with a "childish optimism as to the possibility for their implementation". 77 At the same time, however, Bogusław Leśnodorski opines against an overly hasty disavowal of the usefulness of Rousseau's deliberations. "In spite of the excesses of which [Rousseau] was well-aware, in this country he found an expression of some imperfect, yet praiseworthy ideal of civic freedom" ${ }^{78}$ and this is what is accented in his writings. In effect, Rousseau invoked both progressives (such as Stanisław Staszic or Hugo Kołłataj ${ }^{79}$ ), as well as conservatives, supporters of reform in the republican, classic noble spirit (Adam Wawrzyniec Rzewuski ${ }^{80}$ ). Bogusław Leśnodorski does suggest, however, that it is more appropriate to speak of inspirations rather than borrowings from Rousseau's treatises. ${ }^{81}$ Nevertheless, the remarks remain difficult material for the foreign scholar, owing to their being anchored in the specificities of the Polish political system.

Fr. Gabriel Bonnot de Mably was also an author of works which quickly attained recognition in Poland. In London in 1781, his tract "Du gouvernement et des lois de la Pologne" was published. ${ }^{82}$ This work, already somewhat outdated the time of its publishing, was based on tracts written a decade prior whose roots were in conversations with Wielhorski, and constituted the presentation of polemics by the two writers. ${ }^{83}$ Mably identifies problems similar to those discussed by Rousseauweakness of the legislature in Poland (liberum veto and confederations were said to be a detrimental lawlessness). He does not glorify the local assemblies, the Dietines; just the opposite, he assumes that it is in them the seeds of anarchy were sown, and recommends their role be restricted (which Wielhorski could not abide, proposing only a reduction in 'abuses'). Mably incorrectly, however, perceived the executive in Poland. Under the influence of conversations with Wielhorski, as well as an exchange of opinions in correspondence with Ignacy Bohusz, secretary of the Bar Confederation, radical critics of StanisławAugust, Mably assigns a tremendous role to the king and proposes far-reaching curbs on his power in favour of the Senate. Paradoxically, at the same time he considers it appropriate to put a foreign dynasty

\footnotetext{
${ }^{77}$ Michalski (1977, pp. 109-110).

${ }^{78}$ Leśnodorski (1967, pp. 36-39). Quot. p. 36.

${ }^{79}$ Szyjkowski (1913, pp. 122-156).

${ }^{80}$ Szyjkowski (1913, pp. 156-165).

${ }^{81}$ Leśnodorski (1967, p. 39).

${ }^{82}$ A.M. le Comte Wielhorski, $8^{\circ}$.

${ }^{83}$ Initial Conférences and subsequent "Observations de M. l'abbé de Mably sur la Réforme des Loix de la Pologne adressée à Monsieur le Comte Wielhorski" (1770), "Secondes observations...", "Troisièmes observations...", "Quatrièmes observations..." of Mably; "Observations sur la premiére conference", "Observations sur la seconde conférence", mentioned "Tableau" of Wielhorski: handwritten copies in AGAD, Zbiór Anny Branickiej, sign. 8 (the user has to pay attention to the wrong technical information on specification of microfilms: ref. 8 (sign. 8) as microfilm wrongly marked under 9) and 9 (as microfilm under sign. 10). Cf. also an introduction of Michalski (1995, pp. 5-12) and further analysis pp. 81-83.
} 
on the throne, which would allegedly serve to reduce the risk of internal rivalry. ${ }^{84}$ An interesting idea was that of convening a national assembly ("la nation sera convoquée extraordinairement"), an extraordinary Sejm convened every 25 years, as well as after the death of the king an conclusion of a peace in order to examine abuses of the original, ideal system. Mably writes: "une des fautes principales des législateures en faisant leurs lois, c'est de ne pas donner la faculté de sa rétablir et de se reproduire, pour ainsi dire, par ses propres forces. De là une dégradations journalière et insensible; et enfin des maux extremes auxquels il n'est plus permis de remédier". 85

Fundamentally, the criticism of the legal system in the letters under analysis was unspecific. Mably charged Polish law with being ineffective, and that there were no real means of enforcing it. Although he appreciated that Polish law was conducive to the practice of civic virtues, he called for reform of the political system: "...rien ne me paroit important que la Pologne commence par se former une constitution. L'histoire de tous les peuples et de tous les siècles démontre l'importance de cette vérité. J'ai remarqué chez toutes Nations qu'un Gouvernement vicieux ou établie sur des mauvais principes a toujour rendu les citoyens malheureux. Par quell privilège les Polonois ne seroint-ils pas soumis à cette règle générale? J'ai toujours remarqué qu'à mesure qu'un Gouvernement se perfectionne en se rapprochant des bons principes, les citoyens, sans qu'ils s'en apperçoient et pour ainsi dire malgré eux, prennent peu à peu toutes vertus don't ils ont besoin." 86

The result of the reform was to be the fundamental laws, a constitution which would be the source of executive legislation. Mably did not, however, offer details, considering it too early. ${ }^{87}$ Although some of his remarks addressing the judiciary, such as the postulates of openness, permitting the bourgeoisie to participate in the administration of justice (Mably most likely was unfamiliar with the estate model of judiciary in Poland) were of a substantive nature, he was not able to provide specific proposals of institutional reform. He limited himself rather to generalizations about the necessity of observing "the highest standards of justice" ("régles de la plus éxacte justice" 88 to be applied by the chancellor's tribunal and which could set a

\footnotetext{
${ }^{84}$ Michalski (1995, pp. 90-92, 175, 179-182).

85“'Secondes observations de m. l'Abbe de Mably; sur la Reforme des Loix en Pologne à Monsieur le Comte Wielhorski”, AGAD, Zbiór Anny Branickiej 9 (microfilm marked as 10), k. 267 (old pagination below: k. 136). Also Michalski (1995, pp. 180-181).

86“'Troisiêmes Observations de Monsieur l'Abbe de Mably sur la Reforme des Loix en Pologne à Monsieurs le Comte Wielhorski", AGAD, Zbiór Anny Branickiej, sign. 9 (ref. 9 on microfilm under ref. 10), k. 311 (old pagination below k. 158v).

${ }^{87}$ Michalski (1995, p. 94). Mably devoted to executive power an elaboration entitled "Seconde Conférence", AGAD, Zbiór Anny Branickiej, Archiwalia różnej proweniencji, sign. 8 (ref. 8 on microfilm under ref. 9), pp. 95-103 (pagination below 51-54v) and later the second chapter: "De la Puissance Éxécutrice du Roi" of mentioned "Observations de M. l'abbé de Mably sur la Réforme des Loix de la Pologne adressée à Monsieur le Comte Wielhorski”, sign. 9, pp. 27-54 (pagination below 14r-27r).

${ }^{88}$ „Troisiême Conference”, AGAD, Zbiór Anny Branickiej, Archiwalia różnej proweniencji, sign. 8 (on microfilm on ref. 9), k. 104 (pagination below 55v).
} 
relevant example for other courts), "the principals of humanity" ("régles de l'humanité" ${ }^{\prime 89}$ ), which was supposed to influence citizens' trust in the state and the law. ${ }^{90}$ Particularly harsh assessment is warranted by Mably's recommendations concerning foreign policy - the fiasco of his analysis (e.g. of Prussia's neutral attitude towards Poland) demonstrated the circumstances around the first partition. ${ }^{91}$

Mably arrived to Poland in 1776; his correspondence from that period betrays a deep disappointment at the real state of things. He compared the subjective vision of Polish relations presented to him by confederates with political reality; more pain came with remarks on the situation of the bourgoisie, peasantry, and the Jewish population, which we may find in "De la situation de la Pologne en 1776", published after the author's death. ${ }^{92}$ Mably's visit also impacted the shape of the final version of the previously-mentioned tract.

Both of those treatises remained idealized and moralizing lectures: the thinkers were viewing things through "two lenses: their own ideas, plus the information and judgements delivered by Wielhorski". ${ }^{33}$ Both of the propositions presented were of a republican slant, emphasizing reinforcement of the legislative authority at the cost of what they felt was the most usurpatory, id est the monarchial, which demonstrates a detachment from Polish reality in which the central executive was in a state of decomposition, while no local one existed. Mably was no fan of direct democracy, whose materialization Rousseau perceived in the assemblies. Rousseau, however, was a supporter of an effective executive, whereas Mably in turn sought to weaken it through an internal division.

It is a sort of paradox that the conceptions of the two writers were used to achieve utterly opposite aims - the postulates of the movement to weaken the king through the actions of the Permanent Council (Rada Nieustająca) following the first partition, as well as the postulates of the baronial opposition against the Permanent Council, appealing to "the true nation", id est the landed provincial gentry. During the era of the Four-Year Sejm, politicians from the patriotic camp like Ignacy Potocki and, somewhat later, Kołłątaj, taking their inspiration initially from Rousseau and Mably, came to adopt a less radical and far more realistic position. ${ }^{94}$ Anna Grześkowiak-Krwawicz perceives in Polish political thought of the day a surprising "capacity to interweave theoretical considerations into current political

\footnotetext{
${ }^{89}$ „Troisiême Conference”, AGAD, Zbiór Anny Branickiej, Archiwalia różnej proweniencji, sign. 8 (on microfilm on ref. 9), k. 105 (pagination below k. 56).

${ }^{90}$ Cf. „Troisiême Conference”, AGAD, Zbiór Anny Branickiej, Archiwalia różnej proweniencji, sign. 8 (on microfilm on ref. 9), k. 103-111 (pagination below 55-59); Michalski (1995, pp. 93-94).

${ }^{91}$ Michalski (1995, pp. 198-199).

${ }^{92}$ Michalski (1995, pp. 206-221).

${ }^{93}$ So Michalski about Mably (Michalski 1995, Sarmacki..., pp. 242-243), but the same can be said of Rousseau.

${ }^{94}$ Michalski (1983).
} 
reasoning", even if it proved impossible to develop an original concept of the social contract. ${ }^{95}$ This was also the case with the concepts referred to above.

Above generally outlined drafts did not become a direct basis for legislative process in Poland. It should be noted that references to Rousseau concept had already been made during the constitutional debate in the Great Sejm era (after 1788), however they had been of a general character.

\section{The Extraordinary Procedure for Enactment of the Constitution of 3 May: Oath on the Constitution}

\subsection{First Constitutional Works}

The name referred to in preceding chapters attests to the desire to distinguish the adopted Government Act from "normal" parliamentary legislation. It should be borne in mind that the procedure for enacting the Constitution deviated significantly from both parliamentary procedure and custom.

As has been mentioned, the deputies of the Great Sejm (from 16 December 1790 sitting in double composition) were aware of the breakthrough taking place in the moment. Evidence of this comes from the amazing awakening of the political nobility, reflected inter alia in the rash of opinion journalism, ${ }^{96}$ but also activity during provincial sessions in October $1788 .{ }^{97}$ On 7 September 1789, the anniversary of the election of Stanisław August, the deputation of parliament was selected and entrusted with preparing the form of government in these words: members of the deputation "Cardinal laws, duties of sovereign magistracies, authority and appropriateness in between, in short the whole form of political government the States of the Republic shall describe and design: if anyone wishes to submit their ideas, they will be accepted and considered, and the complete work shall be left to the Decision of Us, the King and the States of the Republic". ${ }^{98}$ Its members were

\footnotetext{
${ }^{95}$ Grześkowiak-Krwawicz (2000b, p. 125).

${ }^{96}$ Grześkowiak-Krwawicz (2000a, Introduction, pp. 15-68).

${ }^{97}$ Szczygielski (1994a, 2009).

${ }^{98}$ In text paraphrased translations; in length as followed:
}

„Wyznaczenie Osób do ułożenia Proiektów do Formy Rządu. Gdy pomyślność Narodu, a w niey ugruntowana Sława Nas Króla, i beśpieczeństwo Obywatela od trwałości Rządu zawisły. Pomnożone zaś Woysko, powiększone dochody publiczne bez utworzenia nieodmiennych Ustaw, urządzenia i rozdziału Władz Magistratur, i ich między sobą związków, szkodliwym stawałyby się ciężarem, a sama wewnętrzna spokoyność, którą zapewniać za cel troskliwości Naszey mamy, wzruszoną bydźby mogła; Przeto My Król zawsze z ukochanym Narodem złączeni, chcąc dwudziestopięcioletnie trudy dla Kraiu czynione przyłożeniem się do iego szczęścia mieć nadgrodzonemi wraz z Rzeczypospolitey Skonfederowanemi Stanami do takowego Dzieła naydokładnieyszego rozważenia Osoby następuiące wyznaczamy (...), Którzy Prawa Kardynalne, Magistratur Zwierzchnich obowiązki, Władzę, i między niemi stosowność, zgoła całą Rządu Politycznego Państw Rzpltey Formę opiszą, Proiekta, ieżeli kto zechce podawać do tey materyi 
both progressive parliamentarians, such as the Lithuanian vice-chancellor Chreptowicz, Lithuanian Court Marshal Potocki, and Lithuanian deputy Józef Weyssenhoff, as well as conservatives such as Krasiński, the Bishop of Kamieniec.

In December 1789, the deputation proposed "Principles to improve the form of government" (Zasady do poprawy formy rzadu), which were significantly revised during the subsequent debate, and finally passed and entered into the borough books on December 23. ${ }^{99}$ The original text by Ignacy Potocki ${ }^{100}$ was considered too revolutionary; the final outcome highlighted the role of the nobility. The terms "nation" and "people" disappeared from the text, and the term "The Republic" appeared in their place.

Also, the comprehensive "Form of government draft" (681 articles in 11 chapters) did not meet the expectations of the deputies. Initially only a part of the whole was tabled, i.e. only a draft law on regional councils, but deputies demanded that the entire draft reforming the state system be submitted, which was effected on 2 August 1790. A special part of the draft accounted for 89 articles under the title "Constitutional rights and cardinal rights within them", "the first comprehensive attempt to formulate the principles of the political system in a single act". ${ }^{101}$

The draft, again composed largely by Potocki and strongly republican, emphasized the role of councils and parliament with a weak position assigned to a hereditary monarch, was not adopted by deputies. The issue of the order of succession was delegated to the councils, and it was their role to consider the possibility of appointing Frederick Augustus Wettin as Stanisław August's successor. The debate went on from September 1790 with consultation on "Cardinal Laws" draft to January 1791, at which point the deputies decided to suspend their deliberations and return to the law on regional councils. The king wrote to Deboli: "It is perhaps the task of Marshal Małachowski to begin the Form of the Government from the Assemblies, and not from a continuation of the Cardinal Laws, as through those Cardinal Laws we would quickly arrive to the matter of Succession or Election, which we must most assuredly delay, insofar as the Saxonian Elector himself wishes for there to be no decision as he is becoming aware that the Vienna and Moscow courts, which opposed that at once, are now displaying malevolence (?) towards Him". ${ }^{102}$

Ultimately it turned out that only the "Cardinal Laws" came into force, yet they were cut down to a mere 11 articles, were passed and entered into force, which was

ściągaiące się, przyimą, i rozważą, całkowite zaś Dzieło do Decyzyi Nam Królowi i Stanom Rzeczypospolitey przyniosą".

Sessya Seymowa 155, 14th September 1789, cf. transcribed version of Biblioteka Kórnicka: http://www.wbc.poznan.pl/dlibra/publication?id=20152\&tab=3 (2016-10-03). Text also: Volumina Legum, Vol. IX, p. 107.

${ }^{99}$ Zasady do poprawy formy rządu, Volumina Legum, Wydawnictwo Komisyi Prawniczej Akademii Umiejętności w Krakowie, t. IX, Kraków 1889, pp. 157-159.

${ }^{100}$ AGAD, APP, sygn. 98, k. 159 and forthcoming.

${ }^{101}$ Szcząska (1990, p. 41). Cf. also Leśnodorski (1951, pp. 147-150).

${ }^{102}$ Letter to Deboli, January 1st, 1791, AGAD, Zbiór Popielów sygn. 413, k. 2. Similarly in the letter of January 5th, k. 4. 
an unstable compromise. They were eventually published in the borough books by the Speaker of the Sejm, Stanisław Małachowski, on 8 January 1791. ${ }^{103}$

Following the experience described above, it turned out that the submission of any controversial issues about the political system to broader parliamentary discussion led to fruitless deliberations lasting for months. In general the Sejm did not merely "jaw-jaw", but in fact produced a river of verbiage; Bogusław Leśnodorski claims that "there remained a great deal of old-fashioned noble rhetoric in which, among the Ciceronian moments and bloated patriotic phrases, the fundamental idea of picking the Fatherland up after its fall is frequently lost in the mountain of details". 104

From December 1790, the composition of the sitting Sejm was extendedformally speaking, the authorisation of the body had been renewed, and young, reform-orientated deputies entered the parliament. The Patriotic camp became organized and resigned itself to the fact that reform could only take place in consultation with the king. There was tremendous distrust on both sides; the king's tendency to display an excess of sympathy towards Potocki could give rise to the suspicion that a conspiracy had been conceived; on the other hand, antipathy towards Potocki or Małachowski could lead to "demolition of the entire system". 105 The king also had to deal with a personal grievance: "Now Potocki is the beneficiary of an honest and favourable deed which I am performing. And I always do so for precisely that reason for which you, Sir, are writing to me, that the downfall of Małachowski and the Potockis would result in tragedy for our Fatherland. Indeed, I have the greatest possible occasion to take revenge against the Potockis for their long years of mischievousness towards me, but I hope that God saves me from vindictiveness until the end of my days". ${ }^{106}$ The breakup of the previous coteries may also be attested to by the King's record given to Deboli of the somewhat idealistic conversation between Potocki and Branicki, in which the former, when asked about the opinion of his "party" on the subject of events in England, responded thus: "We know of no party, we only wish for all Poles to think and act in the best interests of the country". ${ }^{107}$ The fracture lines had been diagnosed and ultimately work in secret began. After the adoption of the Constitution, on 4 May the king wrote to Deboli that he had been dealing with Potocki and Małachowski for 8 months, but work accelerated when he became convinced of the sincerity of his partners. 108

\footnotetext{
${ }^{103}$ Leśnodorski (1951, pp. 157-160).

${ }^{104}$ Leśnodorski (1951, p. 382).

${ }^{105}$ The king describes this peculiar 'dance' in his letter of January 5th, 1791 to Deboli, AGAD, Zbiór Popielów, sygn. 413, k. 5.

${ }^{106}$ Letter to Deboli, February, 2nd, 1791, AGAD, Zbiór Popielów, sygn. 413, k. 23.

${ }^{107}$ Letter to Deboli, April 13th, 1791, AGAD, Zbiór Popielów, sygn. 413, k. 71.

${ }^{108}$ Letter to Deboli, May 4th, 1791, AGAD, Zbiór Popielów, sygn. 413, k. 82.
} 


\subsection{Enactment of the Government Statute}

The fundamental draft of the constitution was ready by the end of March 1791 . Stanisław August, Ignacy Potocki, Scipione Piattoli-a former secretary of Potocki and then reader of the King who recorded and prepared editorials, Stanisław Małachowski and Hugo Kołłąaj contributed personally to its drafting, not without friction and mutual animosity. The first para-constitutional laws, including the Law on Cities of 18 April 1791, were signs of things to come. ${ }^{109}$

The text of the constitution was to be presented at a session on 5 May, but in the face of the anticipated difficulties and shifts in the international situation-alarming news had come from England ${ }^{110}$ - the decision to speed things up was taken. The first two weeks by law would have been devoted to examining revenue, tedious for a number of deputies, and it was hoped that not everyone would be back in Warsaw immediately after the two-week Easter break. Only those whose support could be counted on were informed about the plot. The opposition, however, learned of the planned date of 5 May and also began to conspire, with strong support from Russian ambassador, Jakov Bulgakov.

The draft text was presented to the public in the afternoon on 2 May in Radziwiłl Palace on Krakowskie Przedmieście street. The text was welcomed enthusiastically by the audience, and the reading was followed by both supporters and opponents of reform scampering away all across the city. Some found themselves drawn to Stanisław Małachowski's house, others to Bulgakov's lounge.

The events of the following day, and primarily the course of the session on 3 May were a sort of theatrum. The application of tried and tested elements of parliamentary strategy can be discerned. ${ }^{111}$ As a means of exerting pressure, the gallery was populated by numerous so-called arbiters, urbanites, and even

\footnotetext{
${ }^{109}$ This phase described among others Dihm (1930). Detailed also by Leśnodorski (1951, pp. 177204 and 205-210).

${ }^{110}$ In 1790 an improvement in relations between Poland and England occurred, and there was likely an attempt at drawing Poland into the Triple Alliance. At the same time, at the beginning of 1791 relations between Russia and coalition members worsened - the Petersburg court was ready to risk a second war rather than submit to Prussian and English pressure over the peace with Turkey. Russian diplomacy was also engaged in activity within the United Kingdom, inspiring Russian-friendly articles in the press and publishing propaganda pamphlets. The Whig opposition spoke out fiercely against PM Pitt, and there was a split in the government which led to suspension of the sending of a war ultimatum to Russia. The Polish court followed English and Prussian preparations for war with significant fear that the country could be engulfed by international conflict, and - strictly in the practical dimension - fear of the effects of armies marching through Polish and Lithuanian territory. Ultimately, Russia, having seen off the threat of a two-front war, forced the Western powers to accept peace with Turkey on Russia's terms. Poland understood that the breaking of war plans and sudden shift in British policy towards Russia meant that the window of opportunity for neutralizing Russia had closed.

${ }^{111}$ Broader: Stroynowski (2013b).
} 
aristocratic ladies from society. ${ }^{112}$ In additional, the reading of carefully-selectedand even partially falsified-reports from abroad at the beginning of the session fomented an atmosphere of gravity and fear. In response to Potocki's question about what means of rescuing the fatherland are available, the King was to have responded that there is a draft constitution already accepted by many. ${ }^{113}$

The text was read in the Sejm on 3 May. This was a further breach of procedural rules. Enacted in January 1791, the Act entitled "Solemn affirmation of order in the Chamber of the present parliament", foresaw the need to print and provide to deputies a copy of the bill, following which debate could begin three days after the text had been distributed. ${ }^{114}$ What is more, the Deputation for the form of governments, appointed to the task, had not read the draft. At the same time it should be noted that instances of Sejm procedures being violated were not at all uncommon. It was assumed that since the Sejm is authorized to enact its own rules, it also enjoys the authority to waive them if the necessity arises (in accordance with the principle of necessitas non habet legem). For example, in a 1 January 1791 letter to Deboli, the King describes how violations of procedures in several rules occurred immediately "on the first day after the law was made". In the same letter he expresses the opinion that adopting "the English manner of parliament" would eliminate both prolixity and excessive haste (the new regulations required crowning the session with some sort of concluded "deed""115). When the Marshal of the Sejm was summoned to adhere to procedures, he was said to have responded "this is not an ordinary session, but a revolutionary one". 116

The supporters of reform were counting on the forbearance of the public gathered in the galleries of the Sejm. ${ }^{117}$ They weren't wrong, the opponents of the Constitution finally bowed to pressure from the public. The Constitution was enacted by acclamation en bloc, and votes for and against were not formally counted. It is estimated that of the 182 representatives present in the hall, 110 senators and deputies were in favour of the Constitution. ${ }^{118}$ The discussion was very lively, sometimes dramatic. The conservative deputy Suchorzewski, a client of the hetmans, attempted as Rejtan to lay down on the ground and shouted "mercifulness for freedom". ${ }^{119}$ As an aside, during the session following adoption of the

\footnotetext{
${ }^{112}$ Their role grew during the times of Stanisław. Andrzej Stroynowski cites a letter of 28 November 1782 from the King to E. Sapieżyna in which the author grumbles about that frequent presence and "care" exercised by the ladies over the Sejm "exceeding all decency of the sexes and their situation” (,nad wszelką przyzwoitość płci i sytuacji swojej”). Stroynowski (2013b, p. 64). May, 4th, 1791, AGAD, Zbiór Popielów sygn. 413, k. 83.
} 
Constitution, Suchorzewski approached Potocki and, attempting to return to him the royal Order of St. Stanislaus, spoke of his plans to leave for America. Potocki and the foreign diplomats present attempted to dissuade him from that trip, explaining that "there he would encounter an executive of greater power than what we have given the king here. Suchorzewski was surprised and remained in doubt as to whether to leave Poland for good". ${ }^{20}$

The opponents of the Constitution called for remarks at a crucial point of the debate did not dare to speak. Finally, the question of the Speaker of the Sejm for the approval of the Chamber to accept the Government's Bill was answered loudly and, it seemed, unanimously. As he himself described in a letter to Deboli, when the King wished to again speak against deputy Zabiełło and raised his hand, the reformers interpreted this as a "sign of oath": „They crowded the throne. And I, seeing that the thing could be done, did it". ${ }^{121}$ The King stood on the throne and took an oath on the Bible before Feliks Turski, the Bishop of Krakow. Giving it a far more serous dimension the King made later many references to that event, one of them being: "It is not the first time that I hear the declaration that by swearing on the Constitution of 3 May I have undertaken never to relent in adhering thereto". ${ }^{122}$ The King identified this moment with the creation of an obligation to remain faithful to the Constitution and to always strive to carry out its provisions. In Art. VII the Constitution established the duty for each future King acceding to the throne to submit "an oath to God and the nation that he shall retain this constitution on Pacta Conventa".

From the hall of the Sejm deputies went to the church of Saint John, where they were welcomed by municipal authorities and the fraternity of Warsaw. After a few speeches, the Constitution was sworn in by speakers given the title of Marshals of the Confederation, bishops, senators and ministers. After returning to the hall of the parliament, the Marshals of the Confederation signed the text of the Constitution. In the evening, members of the parliamentary military commission took an oath to uphold the Constitution at an extraordinary meeting. The people of Warsaw cheered "Hail to the King, Hail to the Constitution".

The next day, 4 May, a group of almost 30 deputies filed an official protest against the Constitution, which, in accordance with procedure, was entered into the borough books. Kołłataj warned of such a possibility, writing the same day to Marshal Stanisław Małachowski "for the town and the city chancelleries to remain closed until the Constitution is appointed, and afterwards that none of them would dare to accept manifests (...) In order to properly confer, and that those who have

\footnotetext{
${ }^{120}$ In King's relations, Suchorzewski was told by Potocki: „zastanie tam moc wykonawczą większą, niżeśmy ją tu dali królowi. Zdziwił się Suchorzewski y został w wątpliwości, czyli Polskę ma rzucać na zawsze", letter to Deboli, May 4th, 1791, AGAD, Zbiór Popielów, sygn. 413, k. 86.

${ }^{121}$ 'Rzucili się hurmem do tronu. A ja widząc, że rzecz się daie zrobić, zrobiłem'. It was said that this was, in the King's opinion, the second miracle after adoption of the bourgeois draft—via the lips of Suchorzewski-in April 1791. Letter to Deboli, May 4th, 1791, AGAD, Zbiór Popielów, sygn. 413 , k. 83.

${ }^{122}$ Głos JKMsci na Sessyi Seymowey 24 Octobris 1791, AGAD, ASCz, sygn. 22, k. 322.
} 
not taken their oath to that Constitution not to grace our Sejm sessions until they swear that oath". ${ }^{123}$ In the protest entered into the books by the chronicler of Warsaw, the legality of the Constitution was called into question by indications of procedural violations and the absence of "pluralitas", a formal vote which would give a decision of the majority.

Among them were declared supporters of the Russian option, but also deputies who had signed the Dietines' instructions for opposition to the abolition of free elections and feared of being accused of violating the Dietines' recommendations. An open defence of the Constitution also sometimes entailed family conflicts. The King wrote to Deboli and informed him that after the conclusion of the session he was approached by Marshal Sapieha, who had been kept in the dark as to the plans for reform, and who, in a rush of emotion, ultimately swore his oath to the Constitution; he also declared his regret that "neither with Mother nor with Uncle is there a place", he was ruined, and the King was his only hope for rescue. ${ }^{124}$

\subsection{An Oath on the Constitution}

Meanwhile, the Marshals of the Confederation continued the process of swearing in key state officials on the Constitution. Among others, Treasury Commission members swore an oath, while key opponents of the Constitution, namely Hetman Franciszek Ksawery Branicki, Seweryn Rzewuski and Stanisław Szczęsny Potocki left Warsaw for Jassy where they established contacts with the court in Moscow.

The Marshals of the Confederation turned to members of the Sejm Constitutional Deputation in order to complete formalities and sign the Government Act. One member of this committee was Bishop Kossakowski, who, despite his oath, refused to sign, explaining that the Deputation could not sign an act which was not adopted unanimously or by a majority in a roll-call vote. Finally, it was decided to entrust the Sejm with the settlement of the dispute between Kossakowski and other members opting for immediate signing.

Therefore, the session of 5 May began with the awarding by the Chamber of unanimous consent for the signing of the Constitution by the Constitutional Deputation, whose members had completed the necessary formalities. ${ }^{125}$ The Declaration of the Assembled Estates, enacted on that day, could play several roles: on the one hand, it was an act remedying the constitution in the words "We solemnly swear to God and Homeland to obey and defend the Constitution with all

\footnotetext{
123، aby kancelarye grodzka i miejske nie były otwarte, aż ta konstytucya oblatowaną będzie, a po oblacie aby żadna nie ważyła się przyjmować manifestów (...) Aby dobrze się naradzić, żeby i, którzy nie zaprzysięgli tej konstytucji, nie znajdowali się na sesyach sejmowych, póki nie zaprzysięgną'. Quotation after Smoleński (1909, p. 278).

${ }^{124}$ Letter to Deboli, May 4th, 1791, AGAD, Zbiór Popielów, sygn. 413, k. 82.

${ }^{125}$ About searching an unanimity wrote also Oraczewski in his letter, May 7th, 1791, AGAD, Zbiór Popielów, sygn. 418, k. 568-570.
} 
means possible."126 One of the key regulations concerned the abolition of old and new laws that were inconsistent with the Constitution. This will be analysed later. The Declaration also consisted of introductory provisions related to the process of taking an oath by the officials of government committees and judges without delay, and within a month for the army, as well as regulations concerning sanctions imposed on those who would dare to oppose the Constitution ("giving an attentive eye on insurance of this constitution"). This intricate procedure provides grounds for the assumption that the Constitution was enacted in two stages. The Declaration was to allay all anxieties related to procedural violations, e.g. the French version of the Constitution prepared at the request of the King and published by Peter Dufour indicates in the title that the Constitution was enacted by acclamation on 3 May and then unanimously sanctioned at the sitting of 5 May. ${ }^{127}$ Civil servants and residents of the Brzeg province gathered in the assemblies (Sejmiki) of 14 February 1792 also wrote of the "Government Constitution of Third and Fifth May 1791" in reporting the swearing of an oath of loyalty. ${ }^{128}$ The title of an English-language publication emphasized the revolutionary nature of the events. ${ }^{129}$

Those absent on 3 May swore an oath. The other absent officials, such as members of the Tax Commission of Lithuania, were ordered to send a Rota and take the oath in the proper office. After a few solemn speeches the parliament proceeded to continue normal operations. The matter of the constitution and the oath returned over the following days, both members who joined and those who had previously remained silent, now wished to comment as supporters of the Constitution. A small group of opponents stressed the indisputable fact of parliamentary procedure being violated in the process of adopting the Constitution. The circumstances of the Constitution's enactment would soon come to serve as a pretext for questioning it. On the one hand, Russian diplomacy and propaganda would emphasise the fact of pressure being put on the deputies: "The castle and the Sejm Chamber were crowded with the common people of Warsaw, armed men were brought in, the cannons, an artillery regiment and the Lithuanian Guard were gathered to support the common people, they were turned against those who were feared the most, the opposition". ${ }^{130}$

On the other hand, strictly legal arguments appeared, i.e. undermining the Sejm's legitimacy to enact the Constitution, from the liberal interpretation that the

\footnotetext{
${ }^{126}$ Cf. Izdebski (1998, pp. 15-16).

${ }^{127}$ Forme constitutionnelle décretée par acclamation dans la séance du 3 mai, et sanctionée á l'unanimité dans la séance suivante du 5 mai 1791, P. Dufour, Warsaw 1791. Cf. Izdebski (1998, pp. 15-16).

${ }^{128}$ Czartoryski Library, rkps (manuscript) 929, p. 63.

${ }^{129}$ New Constitution of the Government of Poland, Established by revolution, The Third of May, 1791, J. Debrett, London 1791.

${ }^{130}$ 'Zamek y Izba Seymowa napełnione były pospólstwem Warszawy, wprowadzono do niey lud uzbrojony, wytoczono z Arsenału Armaty, Regiment Artyleryi, y Gwardie Litewskie zgromadzono do wsparcia pospólstwa, zapalczywość jego pobudzono przeciwko osobom, których się lękano opozycyi', Deklaracyia, AGAD, ASCz, sygn. 24, k. 81.
} 
parliament had extended its term of office in contravention of the law to the raising of procedural issues, such as the absence of a fair number of deputies and an actual lack of unanimity among the deputies present. Unanimity was not a legal condition as the Sejm was confederated, but the process of formal vote counting was not carried out. It also must be emphasised that enactment of the Constitution did not imply a change in the understanding of sovereignty, and neither did the composition of those wielding power. As far as procedural provisions are concerned, they has been breached before with the rule holding that the Sejm has the power to adopt regulations but also to withdraw them when needed (necessitas non habet legem). ${ }^{131}$ The Saxon deputy Essen also wrote to Dresden about "strong ferment" and the presence of 10,000 burghers greeting the king and the elector. However, he explained in extensive detail that "It is said that many deceptive means were employed to frighten the Russian partisans in the Sejm, by placing a mob in the castle courtyard and having them occupy all the seats. Nevertheless (...) I wish to emphasize with all seriousness that the threat of a new partition has made such a strong impression that even if various superior considerations prevent the elector from consenting to the Polish proposals, (...) it would seem that agreement could be found to turn the throne over to any prince, or even a common nobleman, as long as the idea of an inherited throne could be instituted and by the same token Poland could free itself from the influences of Austria and Russia." 132

The Marshals of the Sejm and the Confederation made a solemn proclamation, informing the public about the adopted Constitution. The text for the oath of allegiance to the Constitution for deputies and "military persons" stationed overseas was also drafted. Congratulations poured in from around the country and from abroad, and there was mention of the Polish Constitution in the British and French parliaments. The monarch handed out "Constitution rings", in snuffboxes, and even buttons and belts were engraved with the commemorative dates.

The King reinforced this mood through his speeches in the Sejm, swearing that he would only abandon the Constitution "upon his death". 133 Diplomatic correspondence was also employed in his manoeuvring. The King did not hesitate to make use of extensive manipulations and censorship, for example by editing out of incoming message troubling fragments about the reticence of the elector and the Vienna court. The Prussian ambassador, Girolamo Lucchesini, who viewed the Constitution as a house built on sand, opined against presenting the Prussian King as a reliable ally of reform in Poland. He criticized the naivety of Polish diplomacy, correctly pointing out that the Saxon elector did not take the decision on his own, but only in concert with the neighbouring powers. However, at the same time he worked to convince the Prussian King that Russian intervention in Poland should

\footnotetext{
${ }^{131}$ Uruszczak (2011, p. 25).

${ }^{132}$ Letter of Franciszek Essen to the Minister of Foreign Affairs Johann Loss, of 7 May 1791, No. 22, in: Kocój (2000, p. 41).

${ }^{133}$ „que je n'abandonnerai qu'avec la vie la loi du 3 mai”. Letter of the King to Józef Poniatowski [Warszawa] 30.IX.1791, Dembiński (1904, p. 45).
} 
not be expected. Letters to Berlin are replete with negative commentaries on the Constitution, wild exaggerations of the number of those opposed to it, and criticism of the French diplomat Descorches, who was said to propagate in Poland (even in Russia, using Poland as a conduit) dangerous democratic ideas. He was resentful of the fact that the King portrayed conversations with Lucchesini as ever so promising for Polish matters, while the attitude of Frederick Wilhelm II was depicted as exceedingly positive towards the Constitution. In Lucchesini's opinion, documents falsified in this way could fool the nobility awaiting the assemblies and convince them that the Constitution enjoyed a "powerful ally" in the Prussian King. The ultimate success - support for the Constitution in the assemblies-was, in Lucchesini's opinion, to be achieved through lies about the acceptance of the crown by the Saxon elector, and the close alliance of Poland with Prussia and Austria. ${ }^{134}$

The independence of the King in this issue was useful in the reorganization the foreign affairs apparatus which was written into the Constitution. Additionally, the king also appointed opponents of the Constitution to the Members of the Guard of the Laws; their presence can be attributed to activities taking place behind the scenes. The King was rightfully afraid of betrayal by them, although this might have been a mere excuse in light of the ignorance in which the Guardianssupporters of the patriotic camp-were kept.

The activities being described here comprise a sort of propaganda campaign, directed largely at creating a favourable climate for the Constitution outside the capital. The Act of 3 May was essentially an initiative of Warsaw and, to a smaller degree, some of the larger cities; greater resistance was expected in the countryside. On 14 May the King reported to Deboli that "Emissaries for the Revolution have gone out in great numbers". ${ }^{135}$ Meanwhile, the mood in the countryside seemed favourable: "Several dozen Civilian and Military Commissions from the Crown and from Lithuania have sent their delegates, while others have forwarded letters attesting to their support of the work of 3 May", the King reported to Deboli. ${ }^{136}$ Undoubtedly a significant role in these "spontaneous" events was played by the aforementioned trusted deputies - for example, the deputy of Wieluń Mączyński wrote to the King about his gathering of citizens "of the entire district" who had sworn their allegiance to the 3 May Constitution and assigned deputies to present their expressions of gratitude to the monarch. ${ }^{137}$ In turn, the citizens of Bracław wrote with regret to the Gazeta Narodowa Y Obca that no oath-taking had been done in their city, and recalled that the "lover of the Constitution and of the deeds of the present Sejm", id est the chamberlain of Bracław, Bogdan Ostrowski, had even thrown two ceremonial balls and that "the whole of the Bracław populace and that

\footnotetext{
${ }^{134}$ Kocój (2006).

${ }^{135}$ 'Rozesłańców za Rewolucją apostołuiących iuż wyiechało, y wyieżdża dosyć', letter of the King to Deboli, 14th May 1791, AGAD, Zbiór Popielów, sygn. 413, pp. 92-94.

${ }^{136}$ Letter of the King to Deboli, Varsovie ce 24.7bre 1791, AGAD, Zbiór Popielów, sygn. 413, k. 194.

${ }^{137}$ Letter of deputy from Wieluń W. Mączyński to the King, de 28. Junii 1791, Biblioteka Czartoryskich, rkps. 734, p. 337.
} 
of the surrounding towns, 600 in all, had gathered" at the parish church on 4 February to declare their loyalty to His Royal Highness of the Republic in defence of the 3 May Constitution. ${ }^{138}$

A final referendum on national consent were supposed the Regional Council (the Dietines) sittings of 14 February 1792 became-out of 78 Councils 70 expressed their approval of the Constitution by taking an oath, vouching or expressing their gratitude to the King and the Sejm for the enactment. ${ }^{139}$ Successive editions of Gazeta Narodowa Y Obca reported on ceremonies organized in the countryside where oaths on the Constitution were taken, cannon volleys fired in salute, ceremonial masses and festivals were held during which toasts for the King, the Constitution, and even the succession of the throne were offered. ${ }^{140}$

Some of the deputies who had signed the Dietines' instructions for opposition to the abolition of free elections justified their initial objection towards the Constitution with the fear of being accused of violating the Dietines' recommendations $^{141}$ and changed their position during next months. The assemblies selected their representatives for the anniversary ceremonies held on 3 May 1792. The celebrations were reported in the "Gazette", and were accompanied by appeals to the Nation in conjunction with the outbreak of war in the defence of the Constitution, as well as reports of Russian military actions taken against Poland. ${ }^{142}$

The above description of the circumstances surrounding the adoption of the Constitution leads to a controversial conclusion - in a certain sense, from the very beginning the May Constitution was a myth, the embodiment of a tool for protection against both internal and external threats. No serious constitutional debate was conducted in parliament, nor among polemicists; decisions as to the wording of particular provisions were taken in negotiations between the King, Potocki, Małachowski and Kołłątaj; translations and transpositions of successive versions by

\footnotetext{
${ }^{138}$ Excerpt of the letter to Gazeta Narodowa (Wypis listu pisanego do kantoru Gazet Narodowey z Bracławia dnia 7. Lutego), Suplement do Gazety Narodowey Y Obcey Nro XIV z Warszawy Dnia 18. Lutego Roku 1792, p. 84.

${ }^{139}$ Letters of the King to Deboli-end of February, March 1792, AGAD, Zbiór Popielów, sygn. 413; Szczygielski (1994b).

${ }^{140} \mathrm{Cf}$. also Gazeta Narodowa Y Obca Nro XV z Warszawy we srzode dnia 22. Lutego 1792, p. 85, Nro XVIII z Warszawy w sobotę dnia 3. Marca Roku 1792, pp. 103-104, reports from Merecz county (doniesienia z powiatu mereckiego), Suplement do Nro XXIV z Warszawy dnia 24. Marca 1792.

${ }^{141}$ Głos Jaśnie Wielmożnego Franciszka Mielżyńskiego Starosty Wałeckiego Posła Poznańskiego (Voice of the Poznań Deputy Franciszek Mielżyński) Na Sessyi Dnia 19. Marca Roku 1792 Miany, AGAD, ASCz, sygn. 24, k. 223-224v, there also similar speeches, a similar description is provided by Stanisław August to Deboli in his letter of 21 May 1791, AGAD, Zbiór Popielów, no. 413, p. 96.

${ }^{142}$ The ceremonies in Warsaw and the countryside were related by the Gazeta Narodowa Y Obca, No. XXXVI, z Warszawy w Sobotę Dnia 5. Maia Roku 1792, pp. 213-214, Nro XL z Warszawy w Sobotę dnia 19. Maia Roku 1792, p. 237, Suplement do Nro XV, p. 240, Suplement do Nro XLI, p. 246, Nro XLII z Warszawy z 26 maja 1792, p. 250, Suplement do Nro XLII p. 252, Nro XLIII z 30 maja, p. 256. Smoleński also described these events in: Smoleński (1897, pp. 5-18).
} 
Piattoli and Linowski could also have contributed to editorial changes in the document. This came about for obvious reasons - experiences of work on the draft of "the Form of Government" convinced Potocki not only of the deputation's conservative attitude, but also of the extreme inefficiency of debates. This is not, therefore, a constitution of lawyers, such as that of 1831 in Belgium. It is a constitution of citizens placing their trust in the slogans of the progressive camp, the voices of the 3 May session which emphasized the necessity of adopting the Constitution in the face of international volatility. In a certain sense the Constitution achieved legitimacy later: during the 5 May session, the submission of the oath by civil servants in the following days, and ultimately the decision of the assemblies of 14 February 1792. A thorough analysis of its contents was not really conducted until work was underway on legislation implementing its provisions.

\section{The Problem of the Supreme Law in the Time of the 3 May Debate}

\subsection{Henrician Articles and Pacta Conventa}

Evaluation of the revolutionary 3 May Constitution in the context of its supreme location in the Polish legal system is not a simple task. A particular difficulty here lies in determining the relation between the existing sources of law, including the category of Cardinal Laws, and the new important act "to which all other laws (should) submit".

In particular, three categories should be addressed: the Henrician Articles, Pacta Conventa, and Cardinal Laws. The Polish tradition of recording fundamental rights is very long. In this context we should mention the tradition of the oath taken by each newly elected King through the Henrician Articles (1573). These articles may be referred to as a sort of "estate constitution". They constituted a compromise between the nobility and the magnates, but also between Catholics and infidels, and they constituted a legal barrier against the "absolutum dominium" arbitrary power of the newly-elected Polish King Henri de Valois. ${ }^{143}$ Mention should be made of opinions present in the Polish subject literature that the articles constituted a "fundamental Act" or "constitutional Act", although these claims ${ }^{144}$ are met with

\footnotetext{
${ }^{143}$ Szcząska (1990, pp. 19-20). Newest elaboration of Articuli Henriciani issue: Makiłła (2012, passim).

${ }^{144}$ Among historians Andrzej Stroynowski: cf. Stroynowski (2013a, pp. 27-28); among legal historians f.ex. Lewandowska-Malec (2013, p. 93). strongly Makiłła; cf. his summary: Makiłła (2008, p. 60), Articuli Henriciani as "fundamental constitutional laws", also Makiłła (2014a, pp. 155-168).
} 
the charge of hyperbole in relation to the significance of the articles. ${ }^{145}$ The Henrician Articles survived in their classic form until the second half of the 18th century, when they were transformed by the instrument that was the Cardinal Laws, to be discussed in detail below. ${ }^{146}$

The Pacta Conventa, on the other hand, represented a bilateral agreement concluded by the King and the nation represented by the nobility. Each successive elected King took an oath on the Henrician Articles and entered into a contract, a Pacta Conventa, which could refer to royal grants, marriage, etc. From 1632 the Pacta begin making greater reference to issues of political organization, replacing the Henrician Articles (which from thereon are only rarely invoked); to a lesser degree they refer directly to the personal obligations of the monarch, as they originally did. This is the source of the opinion present in the subject literature that the acts taken together form a sort of sui generis constitution. ${ }^{147}$

The Henrician Articles (Articuli Henriciani) are treated fairly, according to Polish literature, as a kind of prototype for a "Basic Law". A particular argument in favour of the articles' role in establishing a political system is the fact of the unique position they enjoyed in the legal culture of the nobility, coupled even with the conviction of their supremacy, evidenced for example in the slogan "firnamentum publicae libertatis". This theory is dismissed by Tomasz Kucharski, who demonstrates that there is no broader justification for it to be found. ${ }^{148}$ Although we should concede that they are acts regulating key issues of the political system, at the same time Kucharski rightly points out that very few of the principles underlying the system, and whose existence is not in doubt, were stated expresses verbis in the wording of the articles. ${ }^{149}$ The author also questions the supreme power of Pacta Conventa, mainly emphasizing their strictly political role and their capacity to amend only "normal" parliamentary constitutions. The author invoked the authority of such scholars as Gottfried Lengnich, who did not differentiate the legal force of the Pacta and an ordinary constitution. He understands the ritual of reciting the pacts at the beginning of deliberations of every Sejm as rather an expression and exposition of the control function, and by the same token a sort of reminder to the monarch of his obligations as set out by the structure of the state. ${ }^{150}$

Such an agreement was also entered into by Stanisław August at the time of his coronation. Regular invocations to this fact can be found in the parliamentary debate. "The Pacta Conventa was mentioned here: not for I would like to declare

\footnotetext{
${ }^{145}$ This refers to the aforementioned work by Dariusz Makiłła and review by Tomasz Kucharski and Zbigniew Naworski, cf. Kucharski and Naworski (2013) The author, D. Makiłła, also responded to this review in a work given the title "On the first Polish fundamental law. In response to the critics Tomasz Kucharski and Zbigniew Naworski" (2014b). Sceptical voice on constitutional character of Articuli also: Matuszewski (2007, p. 301).

${ }^{146}$ [A.M.] (2010, p. 25, broader: pp. 18-29).

${ }^{147}$ Uruszczak (2013a, p. 223).

${ }^{148}$ Kucharski (2014, pp. 122-129).

${ }^{149}$ Kucharski (2014, pp. 125-126).

${ }^{150}$ Kucharski (2014, pp. 129-131).
} 
against them, as I am most familiar with their sanctity; I would dare not touch them, for fear of committing sacrilege", said Ignacy Potocki, the Lithuanian Court Marshal, during the 9 December 1789 debate over the prerogative of the king to send deputies to foreign courts. ${ }^{151}$ In the course of that same debate, the Czerniechów deputy Czacki referred to the Pacta as a "sacred bond between the King and Nation", whilst deputy chancellor Garnysz emphasized that "Pacta Conventa is an inviolable thing, and the Sejm may not amend it for the Sejm represents only the Nation, while the Pacta was concluded with the entire Nation." 152

These circumstances of the pacts's swearing were invoked by the King on 3 May for fear of being accused of breaking the Pacta Conventa, which might even result in repudiation of allegiance to the ruler. The King requested that the Sejm release him from the corresponding passage of the Pacta which referred to a free election, ${ }^{153}$ and even deputies opposed to the Constitution such as Chomiński from Oshmiana did not hesitate to remind the King of his oath. ${ }^{154}$ Stanisław Szczęsny Potocki made the accusation in a letter sent from Vienna to the king in May 1791: "crushing of the sacred Pacta Conventa", "breaking the links that bind with the Free Nation". ${ }^{155}$ It also mentions that even if the Sejm freed the King from the duties he had sworn to carry out at the election, the Sejm "did not have a mandate from the nation to such a piece of work". Potocki asks "which Voivodeship commissioned its representatives to do so?"156 The King referred to this issue in his anniversary speech on 3 May 1792, indicating that it was the Sejm that relieved the monarch of this duty (i.e. Pacta Conventa) and which called for him to swear allegiance to the Government Act which constitutes the 'Succession Throne', covering the legislative, executive and judiciary in such a way as to do harm to no person and put no man at a disadvantage (...) The entire nation has come to love the

\footnotetext{
${ }^{151}$ 'Wspomniano tu Pakta Konwenta: nie chęcią iakbym miał co rzec przeciw nim, bo aż nad to znam ich świętość, y tykać ich lękałbym się, żebym w świętokradztwo nie popadł', Sessya XXXII, dnia 9 grudnia 1789, Dyariusz Seymu Ordynaryinego pod związkiem Konfederacyi Generalney Oboyga Narodów w Warszawie rozpoczetego Roku Pańskiego 1788, t. I, cz. II, w Warszawie w Drukarni Nadworney J.K. Mci Y Przesw. Kommisyi Edukacyi Narodowey, pp. 357, 360.

${ }^{152}$ 'Pacta Conventa są rzeczy niewzruszone, y od Seymu nawet naruszyć się nie mogące, bo seym reprezentuie tylko Naród, a Pakta zawierane były z całym Narodem'. Sessya XXXII, dnia 9 grudnia 1789, Dyariusz Seymu Ordynaryinego pod związkiem Konfederacyi Generalney Oboyga Narodów w Warszawie rozpoczetego Roku Pańskiego 1788, t. I, cz. II, w Warszawie w Drukarni Nadworney J.K. Mci Y Przesw. Kommisyi Edukacyi Narodowey, p. 360.

${ }^{153}$ Also in a later accusation of the Targowica Confederation against the King and his fear, cf. the letter of the King to Deboli, No 153 Varsovie ce 22. Aout 1792, AGAD, Zbiór Popielów, no. 413, k. 452.

${ }^{154}$ Wegner (1866, p. 181).

${ }^{155}$ Letter of Stanisław Szczęsny Potocki to Stanisław August, May 30th, 1791, AGAD, Zbiór Popielów, sygn. 392, k. 1-2.

156،...które Województwo Reprezentantom swoim takowe dało zlecenie?' Letter of Stanisław Szczęsny Potocki to Stanisław August, May 30th, 1791, AGAD, Zbiór Popielów, sygn. 392, k. 2.
} 
Constitution and expresses it through the Deputies gathered here". ${ }^{157}$ When, in the following months of 1791 the Saxon elector was being lobbied, under the constitution of the future king of Poland, to engage in negotiations, the necessity of appointing a plenipotentiary for matters concerning the Pacta Conventa was indicated. On the other hand, the Saxon elector emphasized those amendments to articles of the Constitution which he expected from the Polish side, such as the potential for the acquisition of throne by not only the Saxon infant but also one of the royal brothers.

\subsection{Cardinal Laws in Polish Tradition and Legal System}

The Polish concept of a Cardinal Law appears to be related to some degree to the French model of fundamental rights. Nevertheless, it should be emphasized that it seems even more closely linked to the medieval theories of Marsilio da Padova, "monarchomachs" theories of contracts concerning power and sovereignty of the people over the ruler. In Poland, the Cardinal Laws particularly helped to reduce the powers of the King and directly expressed the principle of supremacy of the nobility. ${ }^{158}$ Dariusz Makiłła emphasises that the development of the Cardinal Laws did not mean repealing the Henrician Articles according to the principle of lex posterior derogat legi anteriori. ${ }^{159}$ They emerged as a reflection of the evolving viewpoints expressed in the doctrine, and were partially overlapping with the subjective scope of the Henrician Articles while extending or clarifying them as well. ${ }^{160}$ The concept itself was derived either from "cardinalis" or from "cardo", e.g. hinges, "for as the rotation of a door depends on hinges, the entire machine of the Lawmaker's authority and the executive power depend on the Cardinal Laws". ${ }^{161}$

The Cardinal Laws adopted in 1768 and completed in 1775 are crucial for subsequent events and an assessment of history of the eighteenth century. These were first announced in 1767 in the treaty with Russia and fulfilled in the first part of so-called separate second act, added to the treaty and limiting the sovereignty of Poland, emphasizing its position as a Russian protectorate. As announced, the

157،stanowiącey Tron Successyiny, a tak określaiącey trzy Władze, prawodawczą, Wykonawczą, Sądowniczą, że wszystko obeymuiąc, nikogo nie krzywdzi, nikomu przewagi nie daie (...) Naród cały tę Konstytucyę uwielbił, i otym nayuroczyściey zapewnia przez tych zacnych Delegatów.' Mowa jego Królewskiej Mości Dnia 3go Miesiąca Maia Roku 1792 w Kościele świętego Krzyża Miana, AGAD, ASCz, sygn. 24, k. 161v.

${ }^{158}$ Radwański (1952, p. 185).

${ }^{159}$ Makiłła (2012, pp. 490-491).

${ }^{160}$ Kucharski (2014, pp. 122-129).

161 ‘iż iako na Zawiasach zależy obrót drzwi, tak na Prawach Kardynalnych zależy cała machina władzy Prawodawczey y mocy wykonawczey', Myśli o istocie praw kardynalnych, n.p., n.d., [probably: Myśli o istocie praw kardynalnych. (Projekt do prawa na sejmie r. 1790), n.p. 1790]. Biblioteka Uniwersytecka w Toruniu, sygn. Pol 8.III.1945. 
"form of the Polish Government and the freedom of its citizens clearly and inalienably oblige posterity not to allow any circumstances to bring changes to the constitution in its fundamental part". ${ }^{162}$ This act should have "all the powers of validity"; also the assumed "lifetime durability" of the arrangements was emphasized far and wide. The Cardinal Laws of 1768 guaranteed, among other things, neminem captivabimus - the privilege of the nobility, lifelong offices and the royal bestowals, free elections, and the dominant position of the Roman Catholic religion. They primed the limit of the monarch's power reaching for the formula "the king in parliament". 163 This catalogue of rights is theoretically "never likely to change". During the Partition Sejm (1773/1775) an amendment was added that a son or a grandson of an elected king may not himself become king. The Cardinal Laws did not deprive the Henrician Articles expressis verbis of their binding force; the latter were mentioned as 'the fundamental law of 1573' as religious rights were being secured. $^{164}$

The Cardinal Laws of 1768/75 should be legitimately deemed the first act of a permanent nature (the introduction included its overall objective expressis verbis as "once and for all, to permanently secure the form of government and freedom"), and a document in which a more comprehensive attempt was made to regulate systemic principles. They were beyond a doubt much more complete than the Henrician Articles or the subsequent editions of Pacta Conventa. However, it does not appear as if the lawmakers were striving to create a comprehensive set of regulations, but rather in order to secure the status quo against changes. It would be an exaggeration to claim that there was a deliberate intention to place the norms at the peak of the hierarchy of sources of law; however, Tomasz Kucharski makes a legitimate point that "their essence was not to be formally superior in the legal system, but boiled down to serving as an additional (...) guarantee of the established order". 165

The notion of "Cardinal Laws" was also used in political publications by the most outstanding protagonists of the era on both sides of the political spectrumthe Liberals, such as Ignacy Potocki and Hugo Kołłątaj, and the Conservatives, namely Seweryn Rzewuski. Proposals by Kołłątaj and Potocki for categorizing and understanding the meaning of the Cardinal Laws were essentially similar as they related to the content of the political and social system. The possibility of changing these laws was treated differently and an amendment by a qualified majority of $3 / 4$

\footnotetext{
${ }^{162}$ ‘forma rządu Rzeczypospolitej Polskiej i wolność wolnych jej obywateli wyciągają dla potomnych czasów wyraźniejszego i w niczym nigdy nie poruszonego postanowienia, żeby nowe przypadki nie mogły na potym wprowadzać nowe odmiany, które w pospolitym rządzie nie powinny ściągać się do samej fundamentalnej konstytucji', Volumina Legum, Przedruk Zbioru Praw Staraniem XX. Pijarów, w Warszawie od roku 1732 do roku 1782 wydanego, Vol. VII, Petersburg 1860, pp. 250-256; second act, pp. 276-285; citation, pp. 253-254.

${ }^{163}$ Leśnodorski (1951, pp. 11-20).

${ }^{164}$ In the Sejm constitution on the rights of dissidents, Volumina Legum, Vol. VII, p. 259, folio 573.

${ }^{165}$ Kucharski (2014, p. 133, cf. 131-133).
} 
of the votes was allowed, while the original version of the Constitution of 3 May included a provision for unanimous consent. ${ }^{166}$ The most extensive concept was that developed by Hugo Kołłataj, including the first category of the laws of nature being inherent and inalienable (not to be breached by any consensus), then the "political general" law, or "the law of the social contract", not subject to amendment, and finally special political rights forming constitutional law, subject to alteration with the consent of a 3/4 majority of the assembly and a unanimous Act of parliament. ${ }^{167}$

Potocki adequately distinguished "Cardinal Laws" from "constitutional rights". In "Principles to improve the form of government" he suggested the introduction of unanimity in respect of Cardinal Laws, 3/4 in decisions on resolutions of war and peace, and an absolute majority in making laws about civil law, military and financial affairs. One of the previous printed versions of the "Rules" envisioned unanimity in instructions of assemblies concerning changes to the Cardinal Laws, a $3 / 4$ majority of instructions in political matters, $2 / 3$ in tax and revenue matters, and a simple majority in respect of civil law and criminal law matters (4 to). ${ }^{168}$ One of the many opponents of Potocki's distinct concepts was bishop Ignacy Massalski, who treasured liberum veto as an expression of freedom and feared that any reforms made to strengthen the state could become a pretext for yet another partition. ${ }^{169}$ In the final edition there is only a general mention that "the will of the Nation as to the law-making of the Sejm is decided either unanimously or by some sort of majority, depending on the Material under consideration. Only in the material of the Cardinal Laws should there be unanimity of the Instructions."170

The introductory document titled "Thoughts on the essence of the Cardinal Laws" was likely a supplement to the draft of $1790,{ }^{171}$ whose author accepted the classification of immutable and fixed Cardinal Laws, and also attempted to outline their essence. He asks where such can exist in a nation "which wishes to have a Legislative authority accompany it?", and answers the question by remarking that "the meaning of words must be agreed upon". He emphasizes that their immutability does not mean that the foreigner or usurper "cannot abolish them, but

\footnotetext{
${ }^{166}$ Radwański (1952, p. 173).

${ }^{167}$ Leśnodorski (1951, pp. 368-371).

${ }^{168}$ Zasady do poprawy rządu (Rules for improvement of the government), 4 to, 1789 (Bibliografia Estreicher Vol. XX, p. 229). The Rules are signed by the "Presiding over the Deputation" bishop Krasicki, but this must be one of the earlier versions still referring to the "Nation" (1mo and successive articles), not "The Republic", as in the version prepared for oblate.

${ }^{169}$ Janeczek (2007, p. 212).

${ }^{170}$ ، wola Narodu co do prawodawstwa władzy Seymowey poruczona, podług gatunku Materyi jednomyślnością, lub różną większością okazywać się będzie. W Materyach tylko Praw Kardynalnych powinna być jednomyślność Instrukcyi.' Zasady do poprawy formy rządu, Volumina Legum, Vol. IX, Kraków 1889, pp. 157-159.

${ }^{171}$ Myśli o istocie praw kardynalnych. (Projekt do prawa na sejmie r. 1790), n.p., 1790. The author used the copy found in a legacy collection of Ignacy Franciszek Stawiarski, Biblioteka Uniwersytecka w Toruniu, sygn. Pol 8.III.1945.
} 
that they may not be abolished without the downfall of the freedom of Citizens and the political freedom of the entire Nation, that they are so bound to the freedom of the Citizen and the Nation that, were they to be abolished, the Citizen would become a Slave, and the Nation would, in whole or in part, find itself brought to heel by the violence of the usurper. Such laws are nothing other than universal maxims which every free Man feels in his heart; this is why they ought to be written down, for the Nation to know what must be taken from the grasp of the Usurper or the violent foreigner by the Law". ${ }^{172}$ The Cardinal Laws are to serve as a template for legislation "as a line which not even the Legislator himself would dare to attempt crossing". These rules for the legislator-what extent the law may be amended, and "what extent the Laws may not be touched insofar as they have not been sacrificed by natural truth and justice". In the draft this category was to include provisions addressing freedom of conscience (on the faith of the ruler, apostasy and tolerance), provisions on the indivisibility and self-rule of the Republic, the protection of the law over all people, and civic freedoms protected in three articles: on freedom of contract, personal safety, and freedom of speech. In the author's opinion the immutable Cardinal Laws should include a chapter on fixed Cardinal Laws which could only be abolished by unanimity of instructions from the assembliesregulations concerning the Sejm, the assemblies, congresses of the people and of the estates, the Republic, and the Executive. ${ }^{173}$

The draft from September 1790 opened with a chapter entitled simply "Constitutional and cardinal laws within them." It was a list of key political solutions which assigned a special role to "cardinal laws", in which the change discussed below would be associated with a rigid mode of introduction. These cardinal laws constituted key decisions on the organization of the state and its supreme authorities, Polish-Lithuanian relations, and the powers of the three estates. The act itself was not constructed properly in terms of legislation; the cardinal regulations were mixed with the so-called constitutional provisions, which were an extension of the former (60 to be precise).

During the debate, and in particular during sessions held in Marshal Małachowski's house, it was decided-as was indicated in "Thoughts..." ("Myśli...") - that among the key regulations "inviolable cardinal laws" and "permanent cardinal laws" would be cleaved off. This distinction was close to Kołłątaj's division into Cardinal Laws "planted on the law of nature" and "planted on political

\footnotetext{
172،wzruszyć nie potrafił, lecz dla tego, że niemogą być wzruszone bez upadku wolności Obywatelskiey y wolności polityczney całego Narodu, że są tak spoione z wolnością Obywatela y Narodu, iż gdyby naruszone były, Obywatel stałby się Niewolnikiem, a Naród w części lub całości zostałby pod przemocą uzurpatora. Takie Prawa nic innego nie są, tylko maxymy powszechne, które każdy wolny Człowiek w sercu swoim czuie; dlatego zaś przepisanemi być powinny, żeby Naród wiedział, czego ma strzec od Uzurpatora y przemocy obcey, żeby każdy Obywatel czuł w sobie, co mu uzurpator lub przemoc obca wydziera, żeby nawet zgnębiony Naród wiedział, co z rąk Uzurpatora lub przemocy obcey odzyskać ma Prawo'. Myśli o istocie praw kardynalnych. (Projekt do prawa na sejmie r. 1790), n.p., 1790, as above.

${ }^{173}$ Myśli o istocie praw kardynalnych. (Projekt do prawa na sejmie r. 1790), n.p., 1790, no pagination.
} 
rights". The cardinal inviolable laws were supposed to be a collection of general principles, including freedom of conscience, personal freedom, freedom of contract, the principle of subordination of law, protection of property and indissolubility of the Republic. ${ }^{174}$ However, this latter issue sparked a fierce debate, as the draft absolutely forbade any alienation or even territorial exchange, which probably resulted from the traumatic experience of the first partition. Potocki, however, argued that "the integrity of the Republic cannot be insured with cardinal laws, but with the government, the military, virtue and customs prevailing in the country". 175

Stroynowski, a deputy of Volyn, also approached the concept of the cardinal principles in the same debate and objected to Suchodolski's intention of introducing a ban on foreign candidates to the throne, saying that he knew no other but this Cardinal Law, which derives from the natural law, or from the divine law, yet these said additional issues were not such, so they should not be included within Cardinal Laws. ${ }^{176}$ Ultimately a portion of the regulations was approved. Work on the final shape of the Form of the Government was drawn out, in January 1791 the deputies continued to bury themselves in fruitless discussions, work on the law of the assemblies, or continue work on the partially finalized discussion of the Cardinal Laws. In opting for the second solution they emphasized the fundamental role of the Cardinal Laws, "truly" constituting the Form of the Government, for "it is the foundation which determines the structure". The Cardinal Laws were applicable to Sejms and assemblies, "and therefore are the source from which the stream of freedom flows, they are the only rule of the Republican Government". Opponents claimed that regulations concerning Sejms and assemblies were the priority, as the "foundation of the freedoms and wellbeing of the Republic", palladium libertatis. At the same time, it was perceived that the Cardinal Laws in and of themselves provided no protection against foreign aggression, something evidenced by the events of 1773 and the "watchful and bravely active Government." It was argued that those adjustments of the Cardinal Laws that had already been made possessed everything crucial for preserving the liberty of the nation. The others should flow from the entirety of the political system, id est detailed regulations on the Form of the Government. Ultimately, on 7 January 1791 the deputies voted to undertake work on an Act on the assemblies with a vote of 174 to 89. The long session, completed at 2:00 at night, was concluded with the recommendation to enshrine the

\footnotetext{
${ }^{174}$ Szcząska (1990, pp. 41-42).

${ }^{175}$ ، całość Rzpltey nie Prawami Kardynalnemi, ale Rządem, Woyskiem, Cnotą i zaprowadzonymi w Kraiu obyczaiami ubezpieczyć tylko można (...)'. Dziennik Czynności Seymu Głównego Ordynaryinego Warszawskiego, pod związkiem konfederacyi Oboyga Narodów agitującego się 1790, Sessya CCCVI, Dnia 3 Września w Piątek (used version: AGAD, ASCz, sygn. 9, p. 81) Cf. also Radwański (1952, pp. 162-163).

${ }^{176}$ 'Ja prawa kardynalnego innego nie znam, tylko to, co wypływa z Prawa Boskiego i z przyrodzenia, to jest, co się rodzi w sercu każdego człowieka $\mathrm{i} w$ jego naturze $\mathrm{i}$ takie prawo ustanowiliśmy (...) To zaś co (?) w sobie rzeczone dodatki, jak nie wypływa ani z prawa Boskiego, ani z prawa przyrodzonego (...) tak do praw kardynalnych należyć niepowinno' (Sessya 30 września 1790, AGAD, ASCz, sygn. 9, p. 567v)'.
} 
Cardinal Laws in the agreed form. ${ }^{177}$ The progressive camp, as indicated, put off the acceptance and publication of the cardinal principles, which were finally adopted on 7 January 1791, fearing the further binding of their hands in the reform process. During the session of 11 January the dithering Marshal Małachowski was given his final rebuke concerning the matter of publication of the Cardinal Laws. ${ }^{178}$ In the adopted text attention is drawn by the particular indication that "by the Cardinal Laws" the invalidity was assured of "all foreign guarantees of the Polish government contrary to the independence of the Republic and detrimental to her self-rule", "and that, under no pretext and from nobody in the Republic, could any such be proposed and adopted". ${ }^{179}$

Lastly, the 3 May Constitution did not use the term "Cardinal Laws". This phrase was associated with the events of 1768 and even there was awareness that the subjective distinction between "cardinal" and "constitutional" law was arbitrary and fictitious. It was considered that the mere use of the term "Cardinal Law" did not give them special durability among other constitutional rights. A proposal to distinguish between "inviolable constitutional rights" and "permanent constitutional rights"180 appeared, but this did not explicitly materialize in any of the articles. Only the privileges of the nobility and the Constitution itself were treated as "inviolable", and the separation of powers was introduced "forever". Each king ascending to the throne had to swear an oath to God and the nation "to preserve the Constitution, on the Pacta Conventa (...) which, like the former, shall bind him".

Bogusław Leśnodorski and, in his footsteps, Zbigniew Radwański, emphasized, that the mere fact of the enactment of the Constitution had not eliminated the concept of inviolable laws, which were to be above or somehow within the Constitution. However, Leśnodorski did write not consistently about the 3 May Constitution taking "the place of previous 'fundamental' and 'cardinal' laws", which in the present author's opinion did not take place if we invoke the understanding of the Cardinal Laws in the same manner as the protagonists, not narrowing the definition down to merely the acts of $1768 / 75$ and encompassing them with the expressis verbis meaning of the immutable laws and Pacta Conventa set out in the Act on the Sejms. ${ }^{181}$

At the end of May 1791, in the course of the debate over the bill on extraordinary Sejms during session 82, the Bracław deputy Seweryn Potocki directly invoked the inviolability of the Constitution by these words: "I have seen no expression of immutable laws in this draft. We have only Laws known as Cardinal, and those are not immutable, as they may be amended by unanimous Instructions.

\footnotetext{
${ }^{177}$ Gazeta Narodowa Y Obca, Nro IV, z Warszawy we srzodę dnia 12. Stycznia Roku 1791, p. 13. ${ }^{178}$ Gazeta Narodowa Y Obca Nro V, z Warszawy w sobotę dnia 15. Stycznia Roku 1791, p. 17.

${ }^{179}$ Art. VII: 'Wszelka cudzoziemska gwarancya rządu Polskiego, przeciwna niepodległości Rzeczypospolitey i uwłaczająca jey samowładności iest i nazawsze będzie nieważną, i aby żadna podobna pod iakimkolwiek bądź pretekstem od nikogo w rzeczypospolitey proponowaną, i przyiętą bydź nie mogła, tym prawem kardynalnym waruiemy'. Prawa kardynalne niewzruszone, Volumina Legum, Vol. IX, Kraków 1889, CCXXXVI, pp. 203-204.

${ }^{180}$ Radwański (1952, p. 174).

${ }^{181}$ Leśnodorski (1951, p. 363).
} 
They tell me that the expression of immutable laws is to be found in the law already adopted on the Sejms. I would implore that we be granted such a Law, as all expressions of it cannot be encompassed by the memory. If, in its very essence, the said expression is contained in that law, I would at least request that we finally clarify what is meant by immutable laws". ${ }^{182}$ In response, Weyssenhoff indicated that in the draft law on ordinary Sejms "there was a provision that the Ordinary Sejm shall not enact anything that would infringe the Act of 3 May and the Cardinal Laws, but it was judged that the expression of immutable laws was preferable to that of Cardinal Laws, and with this expression the Law of the Sejms was passed". ${ }^{183}$ The Lithuanian Marshal lgnacy Potocki explained that in the works of the Deputation a deliberate attempt was made to avoid the concept of "cardinal laws", to avoid associations with the Sejm of 1768; it was also proposed to use the term "eternal", but ultimately the phrase "immutable laws" was applied, to apply to "the sanctity of Religion, freedom, security of life, ownership of property and the entirety of the Republic". ${ }^{184}$ It was also mentioned during a later session that although conclusion of the works could be seen on the horizon, "we are approaching the finish of Our Government [form], and we still do not know what Laws we desire to be immutable from here on out?"185 It can also be noted that such elements regularly appeared in discussion of the Sejm — as late as May 1792 the deputy Siwicki stated that the transfer to the monarch of military rights (under the May Constitution such a solution was to be found in the draft bill on the military commission) is "a threat to liberty", while Marshal Potocki objects, indicating that the voice of the Sejm and of the nation decided unanimously "of the harmony of our government act with the will of the nation". ${ }^{186}$

Ultimately, two closely related Acts, the Act on the Sejms and the Act on Extraordinary Sejms, refered to "the fundamental law under the title of the

\footnotetext{
${ }^{182}$ 'Praw niezwruszonych wyraz znaiduiący się w proiekcie nie znam. Są tylko u nas Prawa pod nazwiskiem Kardynalne y te nie są niewzruszone, gdy za iednomyślnością Instrukcji odmienione, lub poprawione bydź mogą. Mówią mi że ten wyraz niewzruszonych znayduie sę w zapadłym iuż prawie o Seymach. Upraszałbym o rozdanie nam tego Prawa, gdyż pamięcią wszystkich wyrazów Yego obiąć niepodobna. Jeżeli w samey istocie rzeczony wyraz zawiera się w tym prawie, proszę przynaymniey, abyśmy objaśnili w końcu, co to są te prawa niewzruszone'. Sessya 82. Dnia 27. Maja 1791 R., AGAD, ASCz, sygn. 19, pp. 360-360v.

${ }^{183}$ 'była wzmianka, że Seym Ordynaryiny nic stanowić nie będzie coby naruszało Ustawę 3.Maia y Prawa Kardynalne, ale sądzono, że wyraz praw niewzruszonych zamiast Kardynalnych iest lepszy y z tym wyrazem zapadło Prawo o Seymach'. Sessya 82. Dnia 27. Maja 1791 R., AGAD, ASCz, sygn. 19, p. 361.

${ }^{184}$ ‘Świętość Religii, wolność, bezpieczeństwo życia, własność majątku y całość Rzpltey’. Sessya 82. Dnia 27. Maja 1791 R., AGAD, ASCz, sygn. 19, p. 361.

${ }^{185}$ 'zbliżamy się do ukończenia Rządu Naszego a niewiemy dotąd iakie będą Prawa, które za niewzruszone mieć chcemy?' Deputy of Kijów voivodeship, Jan Rybiński, Sejm session 83, AGAD, ASCz, sygn. 19, s. 369v.

186، o zgodności ustawy naszey rządowey z wolnością narodową’, Gazeta Narodowa Y Obca Nro XL z Warszawy w sobotę dnia 19. Maia roku 1792, p. 235.
} 
Government Act and on immutable laws". ${ }^{187}$ The constitutional provisions which should be included in the latter category include the principle of separation of powers, which was mentioned earlier to have been adopted "forever", and the "inviolable" privileges of the nobility.

Thus, as Radwański correctly states, the Cardinal Laws in the post-may sense should not be associated with the assumptions published in January $1791 .{ }^{188}$ It should be noted that the Sejm taken place in Grodno 1793, in abolishing the 3 May legal system, in a formal sense restored the law to its previous state. Its further determinations - the Cardinal Laws of the Grodno Sejm ${ }^{189}$ —were themselves derogated in turn by the Kościuszko rebellion of 1794, which invoked the 3 May laws in respect of those norms they could be applied to in practice. ${ }^{190}$

In the debate of Great Sejm the theories of natural laws of the individual and the community, as well as the Cardinal Laws of the nobility converged. Leśnodorski writes that "the tendencies mixed and intersected". ${ }^{191} \mathrm{He}$ also emphasises an essential difference: while in the West the state does not "issue" laws but "declares" them, in Poland the inviolable rights of the nobility are based on legal 'privileges' and on the authority of the law. ${ }^{192}$ Although e.g. Kołłątaj was a supporter of the first of those ideas, it would seem that the political scene was dominated by the second, with its narrative based not so much in the innate nature of the laws, but rather in the presumption of the binding force of once-granted privileges, the impossibility of their legal negation in light of the principle of sovereignty of the law.

In summary, it is practically self-evident that actors on the political stage intuitively felt that certain determinations by the legislator were of a special nature. There was thus a general conviction as to the existence of immutable Cardinal Laws - anchored in both tradition and in a unique conception of natural law-which no legislative act could amend or abolish. Furthermore, there was a group of legal solutions qualified as fixed or constitutive Cardinal Laws - in respect of which it was held possible to revise by way of unanimous instructions from the assemblies or a qualified majority of them. We can therefore perceive an awareness of the need to institute a hierarchy of sources of law; the protagonists attempted to achieve this, offering various conceptions. These views were not rendered inoperative by the 3 May legislation. As the debate taking place after 3 May has proven, it was rather held that the Government Act was a sort of additional and unclear addition to the existing doctrine, but did not annul it as such. In Poland, fundamental laws did not

\footnotetext{
${ }^{187}$ Volumina Legum, Vol. IX, p. 258.

${ }^{188}$ Radwański (1952, p. 173), Leśnodorski (1951, pp. 364-366).

${ }^{189}$ Volumina Legum, Vol. X. Konstytucje Sejmu Grodzieńskiego z 1793 roku, wyd. Z. Kaczmarek, przy współudziale J. Matuszewskiego, M. Szczanieckiego i J. Wąsickiego, Poznań, nakładem Poznańskiego Towarzystwa Przyjaciół Nauk z zasiłkiem Ministerstwa Szkolnictwa Wyższego i Polskiej Akademii Nauk 1952, pp. 110-113.

${ }^{190}$ Makiłła (2012, pp. 492-493).

${ }^{191}$ Leśnodorski (1951, p. 367). Broader cf. Salmonowicz (1991).

${ }^{192}$ Leśnodorski (1951, p. 372).
} 
serve to mutually undermine one another, and their content intersected like the links of a chain, creating an unbroken continuum.

This fact would seem to negate the contemporary understanding of the constitution as the creation of a "new order", radically overturning existing reality. This is not a characteristic of the May Constitution. However, it is also obvious that, for many reasons, the authors of the Constitution were required to behave tactically and hide their intention of revolutionizing the political order. Fears of accusations that they were engaged in destabilization, the export of French slogans, and the threat of revolution - this constituted an excellent pretext for the intervention of Russian diplomacy and, ultimately, of Russian troops; on the other hand, fears of support for the May law by the conservative nobility in the countryside meant that the constitutional change had to be explained as a delicate revolution, a transformation and modernization of the existing system, id est essentially to smuggle a new regime in under the guise of the existing one.

\section{Relation Between the Constitution and the Ordinary Legislation: Nullification of the Law Contravening to the Constitution}

In undertaking this difficult topic, several issues must be addressed. One is verification of the theory of constitutional regulation and discussion contained in its entirety the principle of supremacy of the 3 May act over other laws adopted by the Sejm. A consequence of this is the creation of a nullification clause regarding law that contradicts the Constitution. It should also be judged whether the practice associated with the May constitution allows us to state that such a clause was, in fact, unequivocally understood in this manner.

The rule of nullifying law contravening the Constitution appears on the basis of Piattoli's version of "Projet de réforme de Constitution in 1791" in Art. 15. ${ }^{193}$ This was yet another edit from the end of January/beginning of February, later translated by Linowski into Polish. This version, just as before, was so marked up that following consultations with Potocki, Marshall Małachowski sent it to Kołłątaj to prepare a new version, which, at the end of March 1791, assumed the form of a text known as "Constitutional Laws". ${ }^{194}$ This was the fundamental reference point for preparing the final version of the text. ${ }^{195}$ The principle of supremacy is also present here, but according to Kołłątaj it should concern the acts of "the present Sejm"; however, following the principles of linguistic interpretation, it would not apply to the law-making of future Sejms.

\footnotetext{
${ }^{193}$ Leśnodorski (1951, pp. 199-200).

${ }^{194}$ Been described in detail by Rostworowski Emanuel (1963, pp. 266-462).

${ }^{195}$ The newest work has been written by Mroziuk (2017).
} 
The Constitution itself in the final draft referred to the title of the problem in two parts, the preamble and the subsequent Declaration of the Assembled Estates. The preamble contained the intention of the legislator, stated as "we adopt this constitution and this entirely sacred and inviolable pledge until that nation at the time prescribed by law, clearly has not recognized a need to alter any of its articles". According to another passage the supremacy of the Constitution was guaranteed in the following words: "To which constitution the further statutes of the present Sejm have to adhere to in all". To quote Feliks Oraczewski, "It was recommended at the session of the Constitutional Deputation the day before yesterday that all the subsequent draft legislation submitted by the government referred to this fundamental act". 196

A particular summation was built into the Declaration in the words "All rights past and present opposed to this Constitution or to any of its articles we abolish, and descriptions specific to articles and any matter in this Constitution confined needed, as specifically detailing the duties and system of government for honour consisting of a Constitution, we declare (...) Having granted universal joy, we place an urgent eye on ensuring the Constitution, stipulating that whoever dared to be opposed to this Constitution or hustle on its corruption, or moved by the peacefulness of good, happy to be starting the nation by implanting distrust, perverse translation of the Constitution... as an enemy country, behind her a traitor, a rebel recognized, the most severe penalties immediately they will be punished by the Sejm court."197 The Declaration thus assumed the punishability of actions against the Constitution. The deputies themselves also perceived a problem with guaranteeing the performance of its regulations, fearing that the lawmaker would be more focused on the creation of law rather than its execution. This was the source of the deputies' postulate to quickly appoint the Sejm Courts, which were to ensure the Constitution was followed, and finally fulfilled during session 82 of 27 May $1791 .^{198}$

These concerns can also be interpreted as an expression of the conviction that not all deputies considered the Constitution to be an exceptional, superior act. Indeed, the lawmaker itself displayed a certain inconsistency, treating the Law on

\footnotetext{
196،Zalecono iest także na Sesyi Zawczorayszey Deputacyi Konstytucyiney stosować wszystkie przepisy dalszych projektów Rządówych do tegoż aktu fundamentalnego', letter of Oraczewski to NN, 7th May 1791, Warszawa, AGAD, Zbiór Popielów, sygn. 418k. 569.

${ }^{197}$ 'Wszystkie prawa dawne i teraźniejsze przeciwne niniejszej Konstytucji lub któremukolwiek jej artykułowi znosimy, a opisy szczególne do artykułów i każdej materii w niniejszej Konstytucji zamkniętych potrzebne, jako dokładniej wyszczególniające obowiązki i układ rządu, za cześć składającą też Konstytucję deklarujemy (...) Uczyniwszy zadosyć radości powszechnej, dajemy pilne oko na ubezpieczenie tej Konstytucji, stanowiąc, iż ktobykolwiek śmiał być przeciwnym niniejszej Konstytucji lub targać się na jej zepsucie, albo wzruszał spokojność dobrego i szczęśliwym być zaczynającego narodu przez zasiewanie nieufności, przewrotne tłumaczenie Konstytucji... ten za nieprzyjaciela ojczyzny, za jej zdrajcę, za buntownika uznany, najsurowszymi karami natychmiast przez sąd sejmowy ukarany będzie'. Deklaracya stanów zgromadzonych, Volumina Legum, Wydawnictwo Komisyi Prawniczej Akademii Umiejętności w Krakowie, Vol. IX, Kraków 1889, pp. 225-226.

${ }^{198}$ Sessya 82, 27 Maia 1791, AGAD, ASCz, sygn. 19, pp. 353-354v.
} 
the royal free Cities as an integral portion of the Constitution (Art. III), and in that manner determining constitutionally the entire issue of the burgher movement. This is the shortest of the articles addressing social classes, with the nobility and the peasantry given far more attention. At the same time, the Act on cities, constituting part of the "3 May system", was adopted following the same legislative procedure as later acts on the Sejm and Extraordinary Sejm, and they were also referred to directly in the wording of the Constitution. Should the entire Act on cities therefore be considered somehow superior to other acts, was this the intention of the lawmaker? Zbigniew Szcząska would seem to make a distinction: he feels that the Act on cities is a component of the Constitution, after which he distinguishes a group of acts "tightly coupled" with the Constitution (the Law on assemblies, "solemnly secured" in Art. VI of the Constitution "as the most important principle of civil liberty"), the Declaration of the Assembled Estates and the Mutual Betrothal of the Two Nations, and finally the executive acts (the Law on the Sejm, the Law on Sejm Courts, the Laws on amnesty, the Guard, the police commission, the military commission, and further laws on cities). ${ }^{199}$ This classification is, however, devoid of any deeper procedural or substantive grounds; it is a presumption grounded in the relationship of the lawmaker expressed in the Constitution to particular content, and is both highly ambiguous and inconsistent. The Act on Sejms clearly sets out two categories of acts adopted by the Sejm: "drafts of the Sejm" ("political, civil, criminal and taxation laws") and Sejm resolutions (one-off acts, acts of contraction, ratification of international treaties).

As results from the deliberations already undertaken, the nullification clause did not imply direct and automatic revocation of the previous fundamental laws. The question must be asked of whether it thus functioned as an instrument of hierarchical control in respect of common legislation, and thus was the mechanism mentioned by Oraczewski in fact applied in practice.

During further legislative work following the adoption of the Government Act, it was indicated that constitutional provisions are contravening to adopted before Law on Guard of the Laws (ustawa o Straży Praw), ${ }^{200}$ because both acts regulated the sphere of executive powers and mutual relations between the king and Members of the Guard in the other way. ${ }^{201}$

The work on Description of the Sejm (Opisanie Sejmu) deserves mention, and its enactment on 12 and 16 May was in its own way an attempt to overcome some of the provisions of the Government Act. As reported by Oraczewski, the changes suggested during the 12 May session were to pertain to the future principles of elections of the senators. The defence against the charge of violating the Constitution consisted in invoking the provision on the royal nomination of senators, and the new provisions

\footnotetext{
${ }^{199}$ Szcząska (1990, p. 47).

${ }^{200}$ Volumina Legum, Vol. IX, Kraków 1889, pp. 266-270.

${ }^{201}$ Voice of the Deputy (lack of the first page with the name of the author), w Drukarni Uprzywileiowaney Michała Grölla, Księgarza Nadwornego J.K. Mości, AGAD, ASCz, sygn. 24, k. 177.
} 
were only to indicate that future kings may nominate only from among two candidates indicated by the each Dietine (Sejmik); this constituted a very creative piece of legislative trickery and was in blatant contradiction with the sense of the constitution's provisions. ${ }^{202}$ The right of clemency was also significantly restricted by excluding "all murders, especially those in ambush and treacherous", pointing to the fact that the king could commission a murder and then pardon the perpetrator. ${ }^{203}$ During this and the following session the provisions of the Sejm resolution were amended to the 'Act of Revolution' and adopted via secret ballot with a vote of 100 to $20 .^{204}$ It was precisely the examples of the aforementioned restrictions in the scope of ius aggratiandi and the appointment of senators that was invoked by the Saxon ambassador Essen in his letter to minister Loss, ${ }^{205}$ expressing his doubts as to the declared and sworn sanctity and immutability of the Constitution. Essen emphasized that these changes came into effect within 6 days of the adoption of the Constitution. In the opinion of the author of a key monograph on the Great Sejm, Bogusław Leśnodorski, legislation following 3 May caused a real shift in the constitutional model towards traditional republicanism. ${ }^{206}$

At the same time, however, the Act on Sejms analysed above contains an extremely interesting decision in Art. XV on the Duties of the Sejm Deputation. Namely, it places the expressis verbis obligation on members of that commission to control submitted drafts with the fundamental law, id est the Government Act (literally: "so that no draft aims at violating and altering the fundamental law given the name Government Act and the immutable laws"207). In the next paragraph this obligation is repeated: according to its wording, drafts are categorized as legislative projects and as Sejm resolutions. The former are broken down into categories such as political, id est "whatever aims at refinement in changing or improving particular descriptions of the Form of the Government, yet always without violating the fundamental law known as the Government Act". ${ }^{208}$ Thus arose a specific obligation of an internal nature to engage in preventative control. To date, the author has been unable to determine whether it was applied in practice, and if so, in what scope.

\footnotetext{
${ }^{202}$ Letter of Oraczewski to NN, in Warsaw May 14th, 1791, AGAD, Zbiór Popielów, sygn. 418, k. 574.

${ }^{203}$ King to Deboli in the letter from 1st June 1791: "Our session of two days previous turned to dividing and diminishing the iuris aggratiandi concentrated in my hands. I allowed this, as I perceived a great but unnecessary shyness in the public" ('Sesya nasza zawczoraysza zeszła na dysceptacyach y umniejszeniu Iuris aggratiandi w moim Ręku. Jam na to zezwolił, bo widziałem wielką lubo niesłuszną o to trwożliwość w publiczności'), AGAD, Zbiór Popielów, 413, k. 112. ${ }^{204}$ AGAD, Zbiór Popielów, 413, k. 574.

${ }^{205}$ Letter of Franciszek Essen to the Minister of Foreign Affairs in Dresden, Johann Loss, of 21 May 1791, No. 26, in: Kocój (2000, pp. 54-55).

${ }^{206}$ Leśnodorski (1951, pp. 164-165). About more examples of contravening provisions cf. Kądziela (2011, pp. 26-27).

207، aby żaden projekt nie dążył do naruszenia i odmiany prawa fundamentalnego pod nazwą Ustawa Rządowa i praw niewzruszonych'. Seymy (Law on Sejms), Art. XV, Volumina Legum, Vol. IX, Kraków 1889, p. 258.

${ }^{208}$ Seymy (Law on Sejms), Volumina Legum, Vol. IX, Kraków 1889, pp. 250-266.
} 
The sequence of the 81 meeting of 26 May might be taken as an example, however not certainly representative: 'There has been a lot of inadmissible opinions that the draft [regarding Senate] should not be taken under consideration and debate because of its contradiction with the Government Statute'. The King declared that he himself, along with the Deputies, had sworn the Constitution in order to protect its integrity, and anything that could violate it would not be accepted. The Chamber admitted the King's words and called to restrain from such violating drafts which 'are time consuming and propagate unfavourable opinion of Legislators, since they have no respect for the sacred laws'. ${ }^{209}$ Marshal of the Sejm obliged himself not to allow the Secretary to read such drafts. ${ }^{210}$ Work on the most important laws of the May system was associated with analysis of constitutional content, which, contradictory to the above-mentioned example, seemed however not to constitute an absolute obstacle.

The King quite clearly stated his position on the possibility of complementing the Constitution's provisions by way of normal legislation. Describing the course of the dispute during the last May session over the position of the Church in the light of constitutional regulation, in a letter of 1 June to Deboli he wrote the following: "Whatever is in the law of 3 May, whatever you Gentlemen swore, whatever I have sworn upon your summons, this law cannot be changed nor violated. Yet since we are now engaged in the details proceeding from this general Law of 3 May, if it occurs among you that there is need to dispel any doubts which none of us could expect when writing the law of 3 May, I shall not object to you in the moment using such words as will best preserve what is my intention until my death that we Poles remain in eternal unity with the Catholic Church under the Papal authority (...)". ${ }^{211}$ Two elements stand out in this statement: on the one hand, the King highlights the impermissibility of violating a provision of the Constitution by normal legislation, and on the other he takes account of the framework character of the Constitution, whose provisions are a point of departure for normal legislation of a particular executive nature. Similar convictions were expressed by the deputy Skarszewski: "It is your duty, most magnificent Estates, to explain and detail this Constitution of the Third of May, in which the Republic of Poland is to be reborn". 212

\footnotetext{
${ }^{209}$ Sesja 81 z 26 maja 1791, AGAD, ASCz, sygn. 19, p. 352.

${ }^{210}$ Sesja 81 z 26 maja 1791, AGAD, ASCz, sygn. 19, p. 352od.

${ }^{211}$ 'Cokolwiek iest w prawie 3. Maja, coście WPanowie zaprzysięgli, com Ja za Waszym powołaniem zaprzysiągł, to odmienionym ani ruszonym z tegoż prawa być nie może. Ale że teraz zatrudniamy się szczegółami wypływaiącemi z tego ogulnego [sic] Prawa 3. Maja, więc ieżeli się WPanom ukazuie potrzeba obiaśnienia tych wątpliwości, których zaiste nikt się nie spodziewał przy pisaniu prawa 3. Maja niesprzeciwię się temu, abyście WPanowie w tych szczegółach teraźnieyszych wpisali takie wyrazy, które naywybitniey ubeśpieczyć mogą to co iest intencją moią do śmierci, abyśmy Polacy zostali w wieczney iedności Kościoła Katolickiego pod iedyną głową Papieską (...)', letter of the King to Deboli, June 1st, 1791, AGAD, Zbiór Popielów, sygn. 413 , k. 113

${ }^{212 ، D o ~ W a s ~ n a l e z ̇ y, ~ p r z e s ́ w i e t n e ~ S t a n y, ~ a b y s ́ c i e ~ K o n s t y t u c y a ̨ ~ t r z e c i e g o ~ M a i a, ~ w ~ k t o ́ r e j ~ m a ~ s i e ̨ ~}$ odrodzić Rzplita Polska, objaśnili w ciągu opisów iey szczególnych’, Głos JW. Imci X. posła Skarszewskiego, Biskupa Hełmskiego i Lubelskiego (Voice of deputy Skarszewski, Bishop of Chełm and Lublin), Na Sessyi Seymowej Dnia 26 Maia Roku 1791, pp. 339-340.
} 
Deputy Korsak several months later spoke of "stewardship of the Republic with the immortal King and the Government Act, as if on a foundation stone" founded. ${ }^{213}$

It would seem vital to inquire as to the extent of which the nullification clause is, in fact, proof of a legal distinction among the sources of law previously developed, and of their subjugation to the constitution. There is no evidence allowing for a definitive answer to the question of how much the deputies themselves distinguished various ranks of key laws and the Constitution. One clue as to the divergent convictions among deputies is a statement made on 31 May by the deputy of Podolian Voivodeship Rzewuski, who concludes "I also agree to other improvements, but in the place where it is written that the successor to the Throne must swear an oath on the Constitution, please add a description of the Constitution intended, for one may suspect that it is only the Constitution which came about on 3 May". ${ }^{214}$ A riposte was provided by the Kraków deputy Linowski: "from hence not all laws are the Government Constitution, firstly, not all laws are of the range of the Constitution, secondly, if the successor were to take his oath on the whole of the Constitution and its elaborations, he would thereby block the route to making later changes as need arises". ${ }^{215}$ Opponents of constitutional provisions expanding the privileges of the monarch invoked the argument that executive acts extend beyond constitutional regulation. ${ }^{216}$

There was a group of deputies, particularly the Constitution's direct authors, whose obvious intention was to create a superior legal act. The Constitution was understood as a framework for normal legislation. In turn, for a portion of the conservative deputies, the May Constitution did not constitute a superior act, and was rather regarded as another variation of the rules improving "the form of government". This was the source of the real attempts at verification of its provisions through normal legislation. Ambassador Essen wrote to Dresden the following

\footnotetext{
${ }^{213}$ Głos J.W.J: Pana Tadeusza Korsaka Seymowego i Ziem. Sędziego Posła Woiewództwa Wileńskiego Na Sessyi Seymowey Dnia 15 marca 1792 Roku (Voice of Deputy of Vilnius Voivodeship Tadeusz Korsak), AGAD, ASCz, sygn. 24, k. 200.

${ }^{214}$ ' $\mathrm{Na}$ inne poprawy równie się zgadzam, ale w tym miejscu, gdzie iest napisano, że następca Tronu na Konstytucyą ma przysięgać proszę dodać na Konstytucyą z iey opisaniem, bo możnaby mniemać, że to tylko iest Konstytucyą, co dnia 3 Maia stanęło'. Sessya 84. Dnia 31 Maja 1791, AGAD, ASCz, sygn. 19, p. $387 \mathrm{v}$.

${ }^{215}$ 'nayprzód nie wszystkie prawa są Konstytucyą Rządową, y powtóre, gdy następca przysięgał na całość Konstytucyi z iey opisami, iużby tym samym zagrodziła się droga czynienia odmian w szczególnościach podług uznania potrzeby'. Sessya 84. Dnia 31 Maja 1791, AGAD, ASCz, sygn. 19, pp. 388-388v.

${ }^{216}($ „P. Siwicki Trocki... Wnosi nakoniec, że gdy koniecznie utrzymać się podoba w proiekcie ten wyraz, którego w całey ustawie rządowey nie czyta: że komisja wojskowa chociażby przeciwną prawu decyzyą króla w Straży, jednak provisorie uskutecznić powinna, domagając się zwołania seymu: aby te provisorie nie rozciągało się do dyslokacyi, i ruszenia woyska bez woli seymu gotowego"). Gazeta Narodowa Y Obca z Warszawy w Sobotę Dnia 19. Maia Roku 1792.
} 
words: "The final text of all articles of the new Constitution will be the subject of debate during future sessions of the Sejm". ${ }^{217}$

The events of 3 May should be perceived as a significant acceleration down the path of reform of the political and administrative system, the creation of a framework for more detailed work. Indeed, as experience had shown that earlier sessions lasting countless hours, which were the subject of complaints particularly after the doubling of the Sejm, did not bring any measurable effects. The method of proceeding on the Draft to the form of government was an utter failure, as the deputies and senators were capable of fighting interminably over the mere shape of the agenda, return to discussing the issue of the assemblies, or engage in work on the Cardinal Laws. After passing the Constitution, legislative work undertaken on the basis of improved procedures accelerated significantly, but violations of it still occurred at times.

The circumstances described would seem to prove that there was still no common, shared conviction as to the particular precedence of the Government Act in the legal system; this view is shared by some contemporary scholars. ${ }^{218}$ The position of parliamentarians as to the supremacy of the Constitution was not, as has been described, consistent. Insofar as the provisions of the Law on Sejms establish an obligation to control drafts against the fundamental law, id est the Government Act, the detailed regulations in the same act concerning the scope of royal authority would doubtlessly be adjudicated from a modern perspective as unconstitutional. In turn, the manner in which the Constitution was celebrated by local assemblies in later months demonstrated that the nobility was aware of how extraordinary the events were, and of the particular nature of the law adopted on 3 May. Acts of celebration, widespread oaths sworn by citizens who did not even hold official offices, celebrations of the anniversary on 3 May 1792 all come together and form a sort of visual dimension. ${ }^{219}$ It cannot be denied that the supremacy of the

\footnotetext{
${ }^{217}$ Letter of Franciszek Essen to the Minister of Foreign Affairs in Dresden, Johann Loss, of 7th May 1791, No. 22, in: Kocój (2000, p. 43).

${ }^{218}$ Matuszewski (2007, p. 301). Totally opposing position by Wacław Uruszczak who regrets that, as the saying "you praise the foreign, but don't know your own" goes, contemporary researchers (P. Tuleja) overlook the legislative achievements of the Grand Sejm in respect of the Constitution's supremacy. Cf. Uruszczak (2013b, p. 252, annot. 23).

${ }^{219}$ Bishop Kossakowski appealed to make 8 May, the day of the patron saint of the King, a holiday for the Constitution. The Sejm adopted a resolution on raising the Temple of the Highest Providence as an expression of gratitude for passing the Government Act. This was written in the Declaration of the Assembled Estates: "For the children of ages to feel all the stronger, that a work so desired, in spite of the greatest difficulties and obstacles, with the aid of the Highest Steward of the fate of nations leading us to our aim, we have not forfeited this joyous moment for the salvation of the nation, we resolve that a church ex voto of all estates be erected in commemoration and consecrated to the highest Providence". The first architectural competition in Poland was announced for a design of the church. A year later, during the anniversary celebrations, a cornerstone was laid; yet by the outbreak of war with Russia, only a chapel was built. Another competition was planned for the twenty years of the inter-war period, after the restoration of independence, but it was initially inconclusive. Ultimately there was an attempt at merging the winning design with an estate planned as a memorial to Józef Piłsudski, who died in 1935.
} 
Constitution crystalized through something other than strictly juridical practice. The theoretical recommendations of the lawmaker about revisions of the Constitution were, for obvious reasons, not implemented.

\section{The Procedure of Constitutional Revision}

Although the preamble to the Constitution consisted of statements declaring the Constitution "sacred and inviolable", this did not mean the intention not to change it in a legal sense, but rather referred to the process of implementing and observing it. ${ }^{220}$

Already on the basis of the "Form of government draft" the first regulations on an amendment of special rights appeared. Modifying the cardinal principles could be done only by unanimity of the Dietines' instruction, whereas ordinary constitutional law and tax law by a majority of 3/4 of instructions, and civil and criminal law-by an absolute majority of instructions. Only for military, education and police affairs was the possibility of amendments with a majority of votes allowed (simple or qualified) without recourse to the instructions of the Dietines.

There were already regulations for revisions in the first draft text of the Constitution itself. Scipione Piattoli's text "Projet de réforme de Constitution" refers to an improvement of the Constitution which can be made through changes based on a $2 / 3$ majority of Dietines' instructions. This, however, does not concern the most important regulations, but only complementary regulation, referred to as the detailed portion (partie réglamentaire) dedicated to the organizational and procedural matters of parliament, and Guard. Suitable "réglements are still adopted by this Sejm and then they shall become part of the Constitution". 221

In his analysis of the revision of the 3 May Constitution, Marian Kallas cites the introduction to the Constitution's draft written by Alexander Linowski. In contrast to the final wording of the Constitution, Linowski's draft represented the "unanimous" rather than the later "clear" (Pol.'wyraźna') will of the people to "recognize the need to alter an article in it [the Constitution]". The later version is an expression of a different, more liberal concept of amending the Constitution. ${ }^{222}$

The Piattoli drafts include plans to amend the Constitution every 20 years unless $4 / 5$ of the Chamber request the convention of an extraordinary meeting, the Constituent Assembly. Another version involved the request to convene the "Convention" by $4 / 5$ of the provinces and when $2 / 3$ of its members opt for change.

\footnotetext{
However, before the outbreak of World War II no serious work was done. After the collapse of the Polish People's Republic the parliament was reminded of the unfulfilled obligation, and both chambers adopted the appropriate resolution in 1998. A cornerstone was laid in 2002. Recently the temple was consecrated, and it is home to the Pantheon of Great Poles and the John Paul II Museum-Institute.

${ }^{220}$ Szmyt (2006, p. 22).

${ }^{221}$ „Projet...”, AGAD, APP, sygn. 197, p. 663; Leśnodorski (1951, p. 199).

${ }^{222}$ Kallas (2001, p. 524).
} 
The original drafts also included concepts such as validity of the constitution (directly associated with Stanisław August) during the reign of only one King (as Pacta Conventa), or amending the Constitution only at the request of the entirety of the nation. ${ }^{223}$

Finally, the 3 May Constitution contains detailed provisions on this issue. It can be assumed that its findings were perceived in advance as requiring clarification and adjustment to changing circumstances, and the constitution on 3 May "was not closed or constant. It was more of a process than a structure." 224 The text of the Constitution contained an announcement of the adoption of further laws, in particular civil and criminal codification. Kołłątaj declared that in addition to the adopted "political constitution" there would come other, economic and moral ones. $^{225}$

The preamble to the 3 May Constitution, as mentioned, refers to the possible need "to alter" the articles of the Constitution. The issue was further developed in Art. VI, which proclaimed "on the one hand preventing abrupt and frequent changes of the national constitution, and on the other, recognizing the need of perfection thereof after experiencing its consequences for the welfare of the public, we establish a twenty-five-year period at the termination of which the revision and improvement of the Constitution should be effected. With a desire to have an extraordinary constitutional Sejm based on a separate description of the law...".226 The term "revision" should be understood as a significant change, while "improvement" is less of a legal definition; rather, we are talking about a process of improvement and refinement. Thus a number of expressions such as variety, correction and revision were used by legislative power inconsistently.

Revision should thus be effected by an extraordinary constitutional Sejm, held every 25 years, and the law on the extraordinary Sejm, the act under discussion, ${ }^{227}$ was a part of the 3 May system.

Debate over the details of the procedure took place inter alia during the 82 nd session on 27 May $1791 .^{228}$ The debate included discussion of the potential to extend sessions beyond the 15 days assumed in the draft, indicating the significance

\footnotetext{
${ }^{223}$ Laszewski (1973, pp. 90, 146-147).

${ }^{224}$ Leśnodorski (1971, p. 422).

${ }^{225}$ Mowa Hugona Kołłątaja na sesji sejmowej 28 VI 1791 R. In: Borowski (1938). Cf. broader on Kołłątaj: Lis (2015, pp. 189-257); also: Dihm (1959), passim, and the discussion around this work, esp. articles of Rostworowski and Dihm's polemics. Finally: Rostworowski (1985).

${ }^{226}$ 'zapobiegając z jednej strony gwałtownym i częstym odmianom konstytucji narodowej, z drugiej uznając potrzebę wydoskonalenia onej po doświadczeniu jej skutków co do pomyślności publicznej, porę i czas rewizyi i poprawy Konstytucji co lat dwadzieścia pięć naznaczamy. Chcąc mieć takowy sejm konstytucyjny ekstraordynaryjny podług osobnego o nim opisu prawa...' Ustawa rządowa, Volumina Legum, Vol. IX, Kraków 1889, CCLXVII, p. 222.

${ }^{227}$ Seym konstytucyiny extra-ordynaryiny (Law on constitutional extraordinary Sejm), Volumina Legum, Vol. IX, Kraków 1889, CCXCVI, pp. 241-243.

${ }^{228}$ Sessya 82. Dnia 27. Maja 1791 R., AGAD, ASCz, sygn. 19v, pp. 353-366.
} 
of matters discussed during the sessions, as well as the issue of a potential collision between an ordinary Sejm and extraordinary one.

The regulation ultimately adopted made extensive use of references to provisions in the Law on Sejms. The same procedure would be akin to the one applicable in an ordinary Sejm, with some exceptions. After the selection of Sejm judges, the "reading of legislative drafts" was supposed to begin. Priority was given to the proposals "given from the throne to local councils", the first "draft of political constitutional rights" (the determinant here is Art. VI, consisting of rights "astringent to the rights contained in the law under the title of Government Act"), followed by "projects to ordinary political rights" (art. 4). The project of amendment, as results from the foregoing, should be already known in advance and discussed during Dietines' sessions, which would give Members a special mandate for reform. ${ }^{229}$ Those would be the carriers of legislative initiatives (Art. 4(2)).

The revision should not impact "immutable laws" nor the Pacta Conventa (Art. VI) - thus, a category of laws with precedence over the Government Act exists! Yet it was not indicated which laws were being referred to-we may presume that one determinant can be the wording of the Constitution itself (the division of powers to be in effect "for all time", the privileges of the nobles to remain "inviolate", personal safety and property "we wish to remain inviolate"). ${ }^{230}$ Control over this was entrusted to the Constitutional Deputation, which could "declare the need" of withdrawing or amending a draft. If the author of the draft did not intend to comply, as under the normal legislative procedure the Deputation should make note of this in its opinion for the Sejm.

The chamber, in the absence of unanimity, was supposed to decide by a simple majority first in an open vote, or if any objections were noted then by secret vote, even if no such motion was tabled. After the reading of the draft and opinion of the constitutional deputation, the Marshal was to ask for the acceptance of the entire draft, or consent to its amendment. In the event of an objection he should ask if it was the deputies' opinion to reject the draft in its entirety, or to amend it; his proposal led only to an affirmative/negative vote. In the event of a majority voting to jettison the draft, it could not again be submitted for voting to that Sejm. If the option to amend the project passed, the Marshal was supposed to allow interested deputies to speak and their remarks were to be presented to the constitutional deputation. This fact could not disrupt the agenda, and the Sejm was to work on the next drafts on the schedule.

The revised draft returned to the chamber, and there was another vote if unanimity as to its adoption in toto could not be reached. Ultimately, drafts on political constitutional laws or political ordinal laws were to proceed to the Senate. Here the King was to speak. Next, the Marshal was to ask the Senate for its opinion, which decided whether the draft should be adopted, which completed the legislative

\footnotetext{
${ }^{229}$ Leśnodorski (1951, p. 283). Szmyt (2006, p. 29).

${ }^{230}$ As Szcząska (1990, p. 61), cited: Leśnodorski (1951, p. 365), and Radwański (1952, pp. 175176).
} 
process, or whether to return it to the other chamber for the deputies to decide again. In the latter case the Senate could only present its "remarks on the desired law, with counsel as to what ought be amended or altered (Art. VII)". The lower house then took steps analogous to those in the first stage, but its decision served to conclude proceedings. The Marshal of the Sejm and members of the constitutional deputation then affixed their signatures to the adopted law, and the secretary sent it for oblation not later than three days. Beyond "constitutional" law, the Extraordinary Sejm would also deal with executive law. Sessions should conclude three months prior to the next ordinary Sejm.

Constitutional reform would constitute a legal obligation, not an optionality, and Andrzej Szmyt rightly cites in this regard the literal interpretation of the Constitution. ${ }^{231}$ The first Extraordinary Sejm was to be convened in 1816 (the date was set for exactly 1 October), so in a time when the Polish lands had already been given another occupational constitution.

\section{Summary}

Understanding of the principle of constitutional precedence raises numerous doubts in the Polish case. Although this rule was stated expressis verbis in the Declaration of the Assembled Estates, previous studies allow for the ascertainment that its content and significance for the legal order was perceived differently. The conclusions that the researcher may arrive are paradoxical, and in their own way even slightly schizophrenic.

The inclusion in the Constitution of assumptions about the special role of the Government Act is a fact. The implementation of a nullification clause in the Declaration of the Assembled Estates is a fact. This was an exceptional invention, a Polish product, and one which would seem an epoch ahead of its time. At the same time, however, in light of experienced practice, we may not accept without reservations the claim of a general recognition of a superior position of constitution towards other sources of law. The Government Act was not a constitutional breakthrough like the acts of revolution in North America and France; it did not overturn an existing social system, but merely reformed a political one without disrupting the evolutionary continuity with the Henrician Articles and the Cardinal Laws. Invoking the words of Leśnodorski: the "fundamental norm" of the previous ancien regime was not subjected to any sort of radical transformation in the reformed political system of the noble Republic. ${ }^{232}$

We may agree as to the purpose of introducing the supremacy clause: first and foremost, it was the desire to guarantee the desired stability of the system, while at

\footnotetext{
${ }^{231}$ Szmyt (2006, pp. 26-27).

${ }^{232}$ Leśnodorski (1951, p. 374).
} 
the same time being aware that the Constitutional Act itself was an act against inter alia the legal state established in the Cardinal Laws (1768/75).

A 'legalistic' narrative turned against the Constitution may be viewed in the acts that were issued from the imperial office in Russia. The most essential accusation made towards the constitution refers to the breach of laws that had previously been taken for permanent and inviolable. This assumed to be unintentionally comical for the contemporary researcher when the authoritarian empress rebukes the reformers for violating freedoms and age-old prerogatives through the fact that the "Throne of Poland was converted from elective to hereditary, and the law dictated by the wisdom of their ancestors, which now forbids to prepare the king's successor while he is still alive, was boldly violated, just as all the other laws which had ensured the sustainability of the Republic". ${ }^{233}$ The other accusation was aimed at the legality of the enactment of the Constitution, i.e. the legitimacy of the Sejm (whose office was extended) and the procedures. The Empress also undermined the process of confirmation of the Constitution by the assemblies (swearing of an oath or sending a congratulatory message in conjunction with its adoption), declaring that "the assemblies were insincere, as they were under threat of arms". ${ }^{234}$

It is difficult to judge how much of an advancement the Constitution was compared to the cardinal laws in the precedence question. The perception of the relationship between the Constitution and acts should be regarded as inconsistent. The key acts, especially the Law on Cities, were straightforwardly regarded as components of the Constitution. One should agree that together they constituted a peculiar "3 May system", yet attributing binding force to them on par with the provisions of the Government Act would be too far-reaching. Last but not least, in the following days and months, the deputies made attempts to introduce regulations into ordinary legislation that were contrary to the Constitution.

However, at the same time the clauses related to the obligation to adjust legislation to the provisions of the Government Act are a much more progressive systemic solution than the vouching of the 'inviolability' of the Cardinal Laws 1768/75 in which, as indicated, they did not result in being ascribed a superior role, and first and foremost they were to serve as inviolable protection against changes in the keystones of the state system. The latter included the privileges of the nobility at once constituting certain components of the political system, such as the free election and liberum veto, which were but derivatives of privileges. As shown by earlier remarks, the adoption of the Constitution did not entail the automatic rejection of the category of inviolable rights, but, quite the contrary, the act of 'system of 3 May' enigmatically invokes this category. It may be understood as an expression of respect for the past in the dimension of social and legal traditions.

\footnotetext{
${ }^{233}$ ‘Tron Polski z Elekcyinego w dziedziczny przemienion, y to Prawo, które mądrość ich przodków dyktowała, y które zabrania za życia króla, zamyślać o obraniu iego Następcy, było równie zuchwale zgwałcone iak wszystkie inne, które zapewniały trwałość nieustaiącą Rzeczypospolitey', Deklaracyia, AGAD, ASCz, sygn. 24, k. 81.

${ }^{234}$ Letter of the King to Deboli, March 21st, 1792, AGAD, Zbiór Popielów, sygn. 413, k. 336.
} 
Contemporary acceptance of the assumption of supremacy of the Constitution leads to the innovative effect of accepting the concept of unconstitutionality, id est the obligation to eliminate from the legal order acts which are incompatible with the Constitution. And again, at the level of the acts comprising the " 3 May system" (on the Sejm and the Extraordinary Sejm), this conception remains implemented to a limited degree. The Sejm deputation was entrusted with the power of preventative constitutional control of draft legislation. However, this was an internal body of the Sejm, whereby it could be subjected to pressure and did not have at its disposal mechanisms that could definitively block an unconstitutional draft. Constitutional practice, which would undoubtedly teem with disagreements over the compliance of acts with the Constitution and which would have to handle the issue of the lack of institutionalised control and of an organ appointed to settle constitutional disputes, was thus never experienced. It should be acknowledged that only an independent judicial organ is capable of imposing a shape on clauses concerning the supreme character of the Constitution. European countries came to this conclusion much, much later. The clause is therefore an unprecedented phenomenon, far ahead of its time.

It would thus seem that the existing situation can be interpreted as a sort of intermediate stage, symbolizing the arrival of a substantive and axiological legal understanding of the Constitution's supremacy. However, had the formal legal stage been reached? Any answer to this question must take into account an ever-present contradiction, a dissonance: although the Constitution was given an exceptionally modern nullification clause, well ahead of its time, in the awareness of many the Government Act constituted only a modernization and dressing-up of the old system. The Constitution was not written in opposition to the old laws, like other acts of modern constitutionalism - and even if this was the intention of the reformers, they were exceptionally circumspect in expressing it - but in response to the international situation, as a means of strengthening the state and countering a potential external threat (per the preamble "for the establishment of freedom, for the salvation of our Fatherland and its borders, with the greatest constancy of spirit"). For this reason the supremacy written into the Constitution should in the first place be associated with the clear effort in many speeches by deputies to create and maintain a lasting system, resistant to sudden change. And most likely this "traditional" perception allowed it to achieve the success of being adopted in May 1791. At the same time, we should objectively assess - and appreciate - the innovative Polish steps along the path of encapsulating the state order in a constitutional act, as well as hierarchization of the legal system, however imperfect they may have been.

Although just one year later the anniversary of the Constitution was celebrated, it was soon followed by Russian intervention and a war in defence of the Constitution. After the defeat, the last Sejm of the Republic of Poland convened in Grodno which, under the pressure of the Russian army, intimidation and abductions of wayward deputies, led to the formal overthrow of the Constitution. Calls for a return to its presumptions in later decades were essentially unrealistic. The Government Act had evolved into the most precious myth accompanying Poles during times of partition and celebrated in the era of freedom. 


\section{Summary (Polish)}

Drugi tom ustaleń projektu badawczego ReConFort poświęcony został zagadnieniu nadrzędności konstytucji. Tymczasem kwestia rozumienia zasady prymatu konstytucji budzi w przypadku polskiej Ustawy Rządowej z 1791 r. rozmaite wątpliwości. Choć zasada ta zostaje wyrażona expressis verbis w towarzyszącej konstytucji Deklaracji Stanów Zgromadzonych, to jednak dotychczasowe badania pozwalają na konstatację, iż jej treści i znaczenie dla porządku prawnego postrzegano w różny sposób. Wnioski, do jakich dochodzi badacz, są na swój sposób paradoksalne.

Faktem jest zawarcie w konstytucji założenia o szczególnej roli ustawy rządowej. Faktem jest wprowadzenie do Deklaracji Stanów Zgromadzonych klauzuli nullifikacyjnej. Był to zupełnie niezwykły wynalazek, powstały na rodzimym gruncie, i zdający się wyprzedzać całą kolejną epokę. Zarazem jednak wobec doświadczonej praktyki - tzn. działań Sejmu Wielkiego w kolejnych tygodniach obrad po uchwaleniu Ustawy Rządowej - nie można bez zastrzeżeń przyjąć tezy o powszechnym uznaniu nadrzędnego charakteru wobec pozostałych źródeł prawa.

Ustawa rządowa nie stanowiła konstytucyjnego przełomu, jak akty rewolucji w Ameryce Północnej i Francji, nie zburzyła istniejącego systemu społecznego, zreformowała jedynie polityczny, nie zrywając ciągłości ewolucyjnej z artykułami henrykowskimi i prawami kardynalnymi. Odwołując się do słów Bogusława Leśnodorskiego: „Norma podstawowa” dotychczasowego starego ustroju nie uległa też $\mathrm{w}$ gruncie rzeczy jakiejś zasadniczej przemianie w reformowanym ustroju Rzeczypospolitej szlacheckiej”. ${ }^{235}$

Zgodzić się należy co do celu wprowadzenia klauzuli nadrzędności: było nim przede wszystkim dążenie do zagwarantowania upragnionej stabilności ustroju przy świadomości, że sam akt konstytucyjny zwrócił się przeciwko stanowi prawnemu utrwalonemu choćby w prawach kardynalnych 1768/75.

Narrację „legalistyczną” skierowaną przeciwko konstytucji prześledzić można w aktach wychodzących z kancelarii imperatorowej rosyjskiej. Podstawowy zarzut stawiany konstytucji odnosi się do złamania praw uchodzących do tej pory za stałe i niezmienne. Przyjęło to niezamierzenie komiczny dla dzisiejszego badacza wyraz, gdy autorytarna imperatorowa gani reformatorów za naruszenie wolności i wiekowych prerogatyw, choćby poprzez fakt, że „Tron Polski z Elekcyinego w dziedziczny przemienion, y to Prawo, które mądrość ich przodków dyktowała, y które zabrania za życia króla, zamyślać o obraniu iego Następcy, było równie zuchwale zgwałcone iak wszystkie inne, które zapewniały trwałość nieustaiącą Rzeczypospolitey". ${ }^{236}$ Drugi z zarzutów, podejmowany przez rodzimych krytyków a następnie dyplomację rosyjską, uderzał w legalność procesu uchwalenia konstytucji, tj. samą legitymację sejmu (którego kadencję przedłużano) a następnie procedury. Imperatorowa podważała także proces swoistego zatwierdzenia

\footnotetext{
${ }^{235}$ Leśnodorski (1951, p. 374).

${ }^{236}$ Deklaracyia, AGAD, ASCz, sygn. 24, k. 81.
} 
konstytucji przez sejmiki (złożenie przysięgi lub przesyłanie gratulacji z powodu uchwalenia), twierdząc, że „sejmiki udały się, bo pod bronią,. ${ }^{237}$

Niełatwo odpowiedzieć na pytanie, na ile konstytucja stanowiła krok do przodu w drodze do nadrzędności systemowej wobec praw kardynalnych 1768/75. Jako niezbyt konsekwentne należy ocenić postrzeganie relacji między konstytucją a ustawami. Kluczowe ustawy, w szczególności prawo o miastach królewskich, wprost uznano za części składowe konstytucji. Zgodzić się należy, że stanowiły one wespół swoisty system 3 Maja, ale przypisanie im wszystkim identycznej mocy obowiązującej, jak przepisom Ustawy Rządowej, należy uznać za nadużycie. Wreszcie, posłowie już w kolejnych dniach i miesiącach sejmu podjęli próby przeprowadzenia w ustawodawstwie zwykłym regulacji sprzecznych z konstytucją, choćby w zakresie królewskiego prawa powoływania senatorów czy ius aggratiandi.

Zarazem jednak bezpośrednie klauzule dotyczące obowiązku dostosowania ustawodawstwa do przepisów Ustawy Rządowej są rozwiązaniem systemowym dużo dalej idącym niż zaręczenia „nienaruszalności” praw kardynalnych, w których, jak wskazano, nie skutkowały one przypisaniem im nadrzędnej roli, a przede wszystkim stanowić miały uroczyste zabezpieczenie przed zmianami w zakresie zworników systemu państwa. Tymi ostatnimi były przywileje szlacheckie stanowiące zarazem pewne komponenty systemu politycznego, jak wolna elekcja i liberum veto. Przyjęcie konstytucji nie oznaczało automatycznego odrzucenia kategorii praw nienaruszalnych, a wręcz odwrotnie, ustawy „systemu 3 Maja” dość enigmatycznie przywołują tę kategorię. Można to zjawisko rozumieć również jako swoisty wyraz poszanowania przeszłości w wymiarze tradycji społecznych i prawnych.

Współcześnie przyjęcie założenia nadrzędności konstytucji jest powiązane $\mathrm{z}$ nowoczesnym skutkiem, akceptacją koncepcji niekonstytucyjności, tj. obowiązku eliminacji $\mathrm{z}$ porządku prawnego ustaw pozbawionych waloru zgodności $\mathrm{z}$ konstytucją. I znów, na poziomie ustaw „systemu 3 Maja” (o Sejmie i Sejmie Ekstra-Ordynaryjnym) ta koncepcja zostaje w ograniczonym stopniu zrealizowana. Deputacji sejmowej powierzono kompetencję prewencyjnej kontroli konstytucyjności projektów ustaw. Był to jednak organ wewnętrzny sejmu, mógł pozostawać zatem podatny na naciski, zarazem nie dysponował mechanizmami trwale blokującymi niekonstytucyjny projekt. Nie dane było zaznać konstytucji praktyki, w której niewątpliwie doszłoby do sporów o zgodność ustaw z konstytucją. Należy zgodzić się, że dopiero niezawisły organ sądowniczy jest w stanie nadać realny kształt klauzulom o nadrzędnym charakterze konstytucji. O tym kraje europejskie przekonały się znacznie, znacznie później. Klauzula jest zatem zjawiskiem niebywałym, wyprzedzającym całą epokę.

Wydaje się zatem, że można interpretować istniejącą sytuację jako swoisty stan pośredni, symbolizujący raczej osiągnięcie fazy prawno-materialnego, aksjologicznego rozumienia nadrzędności konstytucji. Czy jednak osiągnięto już fazę

${ }^{237}$ Letter of the King to Deboli, March 21st, 1792, AGAD, Zbiór Popielów, sygn. 413 k. 336. 
formalno-prawną? Odpowiedź na to pytanie uwzględniać musi tę nieusuwalną sprzeczność, dysonans: choć do konstytucji wprowadzono niezwykle nowoczesną, wyprzedzającą epokę klauzulę nullifikacyjną, to jednak w świadomości wielu ustawa rządowa stanowiła ona jedynie nową, zmodernizowaną szatę starego systemu. Konstytucji nie napisano w otwartej kontrze do starych praw, jak innych aktów nowoczesnego konstytucjonalizmu - a nawet jeśli taka była intencja reformatorów, to wyrażano ją niezwykle oględnie - lecz w kontrze do sytuacji międzynarodowej, jako środek wzmocnienia państwa i przeciwdziałania potencjalnemu zagrożeniu zewnętrznemu (w preambule dosłownie: „dla ugruntowania wolności, dla ocalenia Ojczyzny naszej i jej granic z największą stałością ducha"). Stąd zapisaną w konstytucji nadrzędność należy w pierwszej kolejności kojarzyć z wyrażanym w wielu mowach poselskich dążeniem do utworzenia i zachowania trwałego, odpornego na gwałtowne zmiany systemu. I najprawdopodobniej takie jej „tradycyjne” pojmowanie w ogóle pozwoliło na sukces, na uchwalenie Ustawy Rządowej w maju 1791 r. Jednocześnie należy obiektywnie ocenić - i docenić nowatorskie polskie kroki na drodze do zamknięcia porządku państwowego w akcie konstytucyjnym oraz hierarchizacji systemu prawa, jakiekolwiek chybotliwe by one nie były.

Choć jeszcze rok później uroczyście obchodzono rocznicę uchwalenia konstytucji, to niebawem doszło do interwencji rosyjskiej i wojny w obronie konstytucji. Po przegranej zebrał się w Grodnie ostatni sejm Rzeczypospolitej, który pod naciskiem wojsk rosyjskich, w atmosferze zastraszania i porwań niepokornych posłów doprowadził do formalnego obalenia konstytucji. Nawoływania do powrotu do jej założeń w późniejszych dziesięcioleciach były już w zasadzie nierealne. Ustawa rządowa przekształciła się w najcenniejszy mit, towarzyszący Polakom w dobie zaborów i czczony w epoce wolności.

\section{References}

[A.M.] (2010) Artykuły henrykowskie, prawa kardynalne. In: Leksykon historii prawa i ustroju. 100 podstawowych pojęć, pod red. Prof. Dr hab. Tadeusza Maciejewskiego. CH Beck, Warszawa

Bardach J (2001) Konstytucja 3 Maja i Zaręczenie Wzajemne Obojga Narodów z 1791 r. In: Konstytucja 3 maja 1791. 1791 Gequžes 3-osios Konstitucija. The Constitution of May 3, 1791, z wprowadzeniem naukowym Juliusza Bardacha, 5-52. Wydawnictwo Sejmowe, Warszawa

Borowski S (1938) Kodeks Stanisława Augusta: zbiór dokumentów. Nakładem Towarzystwa Prawniczego w Warszawie, Warszawa, pp 9-19

Dembiński B (ed) (1904) Stanisław August i Książę Józef Poniatowski w świetle własnej korespondencji, Lwów

Dihm J (1930) Przygotowanie Konstytucji 3-go Maja ważnym etapem w urzeczywistnieniu idei niepodległości. In: Pamiętnik V Powszechnego Zjazdu Historyków Polskich w Warszawie 28 listopada do 4 grudnia 1930 r. In: Referaty TI, Tyszkowski K (eds) nakładem Polskiego Towarzystwa Historycznego, Lwów, pp 386-398

Dihm J (1932) Trzeci Maj. Wydawnictwo Naukowo-Literackie, Kraków 
Dihm J (1959) Sprawa Konstytucji Ekonomicznej z 1791 r. (na tle wewnętrznej i zagranicznej sytuacji Polski). Komitet Historii Nauki PAN, Monografie z dziejów nauki i techniki, t. 10, Wrocław

Figeac M (2014) Alphonse Touissant Joseph Andre Fortia de Piles i Louis Boisgelin de Kerdu: Polska w okresie dekadencji swojego bytu państwowego widziana oczami dwóch szlachetnie urodzonych emigrantów. In: Mikołajewska A, Zientara W (eds) Rzeczpospolita w oczach podróżników z Francji I Niemiec. Muzeum Pałacu Króla Jana III w Wilanowie, Warszawa, pp 45-70

Grodziski S (1983) Sejm dawnej Rzeczypospolitej jako najwyższy organ ustawodawczy. Konstytucje sejmowe - pojęcie i próba systematykiy. Czas Prawno-Historyczne XXXV(2): 171-175 (163-175)

Grześkowiak-Krwawicz A (2000a) O formę rządu czy o rząd dusz? Publicystyka polityczna Sejmu Czteroletniego. Instytut Badań Literackich Polskiej Akademii Nauk, Łódź

Grześkowiak-Krwawicz A (2000b) O recepcji idei umowy społecznej w Polsce w czasach stanisławowskich. Czas Prawno-Hist LII(1-2):109-125

Hoensch KJ (1997) Citizen, nation, constitution: the realization and failure of the constitution of 3 May 1791 in light of mutual Polish-French influence. In: Fiszman S (ed) Constitution and reform in eighteenth-century Poland. The constitution of 3 May 1791. Indiana University Polish Studies Center: Indiana University Press, Indianapolis, pp 423-451

Izdebski H (1998) Tryb uchwalenia konstytucji 3 Maja. In: Wyrzykowski M (ed) Tryby uchwalania polskich konstytucji. Instytut Spraw Publicznych, Warszawa, pp 9-17

Jakuboszczak A, Sajkowski W (2014) In: Mikołajewska A, Zientara W (eds) Rzeczpospolita w oczach podróżników z Francji I Niemiec. Muzeum Pałacu Króla Jana III w Wilanowie Rzeczypospolita szlachecka w oczach francuskich preceptorów w drugiej połowie XVIII wieku, Warszawa, pp 71-86

Janeczek Z (2007) Idea wolności w mowach i pismach Ignacego Potockiego. In: Anusik Z (ed) Spory o państwo w dobie nowożytnej: między racją stanu a partykularyzmem. Wydawnictwo Uniwersytetu Łódzkiego, Łódź, pp 201-214

Kądziela Ł (2011) Od konstytucji do insurekcji. Studia nad dziejami Rzeczypospolitej w latach 1791-1794. Wydawnictwo Neriton, Warszawa

Kallas M (2001) Wstępy do polskich konstytucji (1791-1921). In: Gajda E, Sokala A (eds) Honeste vivere... Ksiega pamiątkowa ku czci Profesora Władysława Bojarskiego. Wydaw. Uniwersytetu Mikołaja Kopernika, Toruń, pp 515-535

Kocój H (1988) Misja Feliksa Oraczewskiego w Paryżu podczas Sejmu Wielkiego w świetle jego korespondencji ze Stanisławem Augustem Poniatowskim i Joachimem Chreptiowiczem. In: Lityński A (ed) W dwusetną rocznicę wolnego Sejmu: ludzie - państwo - prawo czasów Sejmu Czteroletniego. Prace Naukowe Uniwersytetu Śląskiego w Katowicach, Katowice, pp 15-40

Kocój H (1996) Prusy, Austria i Rosja wobec Konstytucji 3 Maja. Zagadnienia wybrane, Katowice

Kocój H (ed) (2000) Konstytucja 3 Maja w relacjach posła saskiego Franciszka Essena. Wydawnictwo Uniwersytetu Jagiellońskiego, Kraków

Kocój H (2006) Misja posła pruskiego Lucchesiniego w Warszawie grudzień 1791 - sierpień 1791. In: Prz Nauk Historycznych 2006, R. V., nr. 1(9), pp 292-322

Kucharski T (2012) Konstytucje ,egzorbitancyjne” w Rzeczypospolitej. Czas Prawno-Historyczne LXIV(2):127-159

Kucharski T (2014) Czy szlachecka Rzeczpospolita miała konstytucję? Przyczynek do rozważań nad wykorzystywaniem ustaleń nauki prawa konstytucyjnego do badań historii ustroju. Stud Iurid Thoruniensia XIV:121-146

Kucharski T, Naworski Z (2013) Kilka uwag o najnowszej ocenie artykułów henrykowskich. W związku z pracą Dariusza Makiłły: Artykuły henrykowskie. Geneza-ObowiązywanieStosowanie. Studium historyczno-prawne, wyd. Vizja Press \& IT, Warszawa 2012, ss. 562, Czas Prawno-Historyczne 65(2):409-435 
Łaszewski R (1973) Sejm polski w latach 1764-1793. Studium historyczno-prawne. Warszawa-Poznań, Państwowe Wydawnictwo Naukowe

Leśnodorski B (1951) Dzieło Sejmu Czteroletniego (1788-1792). Studium historyczno-prawne. Wydaw. Zakładu Narodowego im. Ossolińskich, Wrocław

Leśnodorski B (1967) Idee polityczne Jana Jakuba Rousseau w Polsce. In: Wiek XIX; prace, ofiarowane Stefanowi Kieniewiczowi w 60 rocznicę urodzin. In: Kieniewicz S, Grochulska B, Leśnodorski B, Zahorski A (eds) Państwowe Wydawn. Naukowe, Warszawa, pp 29-48

Leśnodorski B (1971) Państwo polskie na przełomie dwu stuleci. In: Leśnodorski B (ed) Polska w epoce Oświecenia. Państwo, społeczeństwo, kultura. Wiedza Powszechna, Warszawa

Leśnodorski B (1975) „,Lagodna rewolucja” w starciu z despotyzmem. Czas Prawno-Historyczne XXVII(2):187-195

Lewandowska-Malec I (2013) Demokracje polskie. Tradycja - współczesność - oczekiwania. Księgarnia Akademicka, Kraków

Lis R (2015) W poszukiwaniu prawdziwej Rzeczypospolitej. Główne nurty myśli politycznej Sejmu Czteroletniego. Akademia Ignatianum. Wydawnictwo WAM, Kraków

Łojek J (1960) Dziennikarze i prasa w Warszawie w XVIII w. Książka i Wiedza, Warszawa

Łojek J (1964) Rok nadziei i rok klęski 1791-1792. Z korespondencji Stanisława Augusta Z posłem polskim w Petersburgu Augustynem Deboli. Wybrał i opracował Jerzy Łojek. Czytelnik, Warszawa

Makiłła D (2008) Historia prawa w Polsce. Wydawnictwa Nau-kowe PWN, Warszawa

Makiłła D (2012) Artykuły henrykowskie (1573-1576). Studium historyczno-prawne. Vizja Press \& IT, Warszawa

Makiłła D (2014a) Artykuły henrykowskie (1573-1576). Zakres wprowadzanych zmian w ustroju Rzeczypospolitej oraz ich ocena. In: Rok 1573. Dokonania przodków sprzed 440 lat. In: Dzięgielewski J, Koehler K, Muszytowska D (eds) Wydawnictwo Uniwersytetu Kardynała Stefana Wyszyńskiego, Warszawa, pp 155-168

Makiłła D (2014b) O pierwszej polskiej ustawie zasadniczej. W odpowiedzi recenzentom Tomaszowi Kucharskiemu i Zbigniewowi Naworskiemu. Czas Historyczno-Prawne LXVI (1):349-366

Matuszewski J (2007) Czy podręcznik powinien być słuszny czy raczej dobry? W związku z pracą Mariana Kallasa „Historia ustroju Polski”, Wydawnictwo Naukowe PWN, Warszawa 2005. Czas Prawno-Historyczne 58(1)

Michalski J (1977) Rousseau i sarmacki republikanizm (in English: Rousseau and Polish republicanism). Państwowe Wydawnictwo Naukowe, Warszawa (Warszawa 2015). http://rcin. org.pl/Content/58076/WA303_78371_JM_Michalski-eng.pdf

Michalski J (1983) Z problematyki republikańskiego nurtu w polskiej reformatorskiej myśli politycznej w XVIII wieku. Kwart Historyczny 90(1-2):327-338

Michalski J (1995) Sarmacki republikanizm w oczach Francuza. Mably i konfederaci barscy. Wydawnictwo Leopoldinum Fundacji dla Uniwersytetu Wrocławskiego, Wrocław

Mottaz E (ed) (1897) Stanislas Poniatowski et Maurice Glayre, Correspondance relative aux partages de la Pologne, Paris

Mroziuk T (2017) Prawa konstytucyjne Hugona Kołłątaja: geneza, treść i znaczenie (in print)

Müßig U (ed) (2016) Reconsidering constitutional formation I. National Sovereignty. A comparative analysis of the juridification by constitution. Studies in the History of Law and Justice 6, ISNN 2198-9842

Pepłowski F (1961) Słownictwo i frazeologia polskiej publicystyki okresu oświecenia i romantyzmu. Państwowy Instytut Wydawniczy, Warszawa

Radwański Z (1952) Prawa kardynalne w Polsce. Poznańskie Towarzystwo Przyjaciół Nauk, Poznań 
Rosner A (1998) Konstytucyjne nadzieje i rozczarowania Polaków w dobie Księstwa Warszawskiego oraz Królestwa Polskiego. In: Wyrzykowski M (ed) Tryby uchwalenia polskich konstytucji. Wyd. Instytut Spraw Publicznych, 19-41 Warszawa

Rostworowski E (1963) Marzenie dobrego obywatela. In: Rostworowski E (ed) Legendy i fakty XVIII wieku. Państwowe Wydawnictwo Naukowe, Warszawa

Rostworowski E (1966) Ostatni król, Geneza i upadek Konstytucji 3 Maja. Wiedza Powszechna, Warszawa

Rostworowski E (1985) Ksiądz Kołłątaj i trzy konstytucje: polityczna, ekonomiczna, moralna. In: Rostworowski E (ed) Popioły i korzenie. Szkice historyczne i rodzinne. Znak, Kraków

Salmonowicz S (1991) Les Droits de l'Homme dans la Constitution du 3 Mai 1791 et la Tradition des Libertés de la Noblese Polonais. In: Justyński J (ed) The origin of human rights. Proceedings at the Seminar May 3-5, 1991, the Nicolaus Copernicus University. Wydawnictwo Adam Marszałek, Toruń, pp 59-68

Salmonowicz S (2001) Między taktyką a ideologią. O rewolucji francuskiej z Warszawy doby insurekcji kościuszkowskiej. In: Kropidłowski Z (red.) Gdańsk - Polska - Europa, praca zbior. pod red. Z. Kropidłowskiego ofiarowana Profesorowi Władysławowi Zajewskiemu w siedemdziesiątą rocznicę urodzin. Wyd. Gdański Instytut Teologiczny, Gdańsk, pp 100-112

Smoleński W (1897) Ostatni rok Sejmu Wielkiego, ed. II. Nakład Księgarni G. Gebethnera i Spółki, Kraków

Smoleński W (1909) Z korespondencji Kołłątaja podczas Sejmu Wielkiego. Prz Historyczny 9(3)

Smoleński W (1927) Monteskiusz w Polsce wieku XVIII nadto fragment pamiętnika autora i zupełna biografja jego pism. Kasa im. Mianowskiego. Instytut Popierania Nauki, Warszawa

Stroynowski A (2013a) Konstytucja, prawo, praworządność w epoce stanisławowskiej. In: „Wieczory sejmowe”. Studia nad dziejami parlamentaryzmu w epoce stanisławowskiej. Wydawnictwo im. Stanisława Podobińskiego Akademii im. Jana Długosza, Częstochowa, pp $25-41$

Stroynowski A (2013b) Metody walki parlamentarnej w czasach stanisławowskich. In: Stroynowski A (ed) „Wieczory sejmowe”. Studia nad dziejami parlamentaryzmu w epoce stanisławowskiej. Wydawnictwo im. Stanisława Podobińskiego Akademii im. Jana Długosza, Częstochowa, pp 59-76

Szcząska Z (1990) Ustawa rządowa z 1791 r. In: Kallas M (ed) Konstytucje Polski: studia monograficzne z dziejów polskiego konstytucjonalizmu. Państwowe Wydawnictwo Naukowe, Warszawa, pp 19-101

Szczygielski W (1994a) Początki łagodnej rewolucji. In: Pamiętnik XIV Powszechnego Zjazdu Historyków Polskich, Łódź 7-10 września 1989 roku. Referaty, komunikaty - sekcje, 143-153. Wydawnictwo Adam Marszałek, Toruń

Szczygielski W (1994b) Referendum trzeciomajowe. Sejmiki lutowe 1792 roku. Wydawnictwo Uniwersytetu Łódzkiego, Łódź, pp 397-396

Szczygielski W (2009) Rola sesji prowincjonalnych w początkach obrad Sejmu Wielkiego. In: Daszyńska J (ed) Konstytucja Stanów Zjednoczonych Ameryki. Reminiscencje w 220 rocznicę uchwalenia. Wydawnictwo Uniwersytetu Łódzkiego, Łódź, pp 159-182

Szmyt A (2006) O rewizji konstytucji 3 Maja 1791 roku. Gdańskie Studia Prawnicze, vol XV

Szyjkowski M (1913) Myśl Jana Jakóba Rousseau w Polsce XVIII w. Akademia Umiejętności, Kraków

Uruszczak W (2011) Konstytucja 3 Maja 1791 r. Testament polityczny I Rzeczypospolitej. Prz Sejm 2(103):9-40

Uruszczak W (2013a) Historia państwa i prawa polskiego, vol I. Wolters Kluwer Polska Sp. z o.o., Warszawa, pp 966-1795

Uruszczak W (2013b) Ustawy okołokonstytucyjne Sejmu Wielkiego z 1791 i 1792 roku. Krak Stud z Historii Państwa i Prawa 6(3):247-258 
Wegner L (1866) Dzieje dnia trzeciego i piątego maja 1791. Nakładem Towarzystwa Przyjaciół Nauk Poznańskiego, Poznań

Wołodkiewicz W (1996) Obraz systemu prawnego Polski w Encyklopedii Diderota. Parlament, prawo, ludzie. Studia ofiarowane Profesorowi Juliuszowi Bardachowi w sześćdziesięciolecie pracy twórczej. Wydawnictwo Sejmowe, Warszawa, pp 347-349

Woźnowski W (1971) Koncepcja literatury walczącej w czasach Stanisława Augusta. Pamięt Lit 62(1):31-55

Zawadzki W (ed) (1963) Polska Stanisławowska w oczach cudzoziemców, vol I-II. Państwowy Instytut Wydawniczy, Warszawa

Open Access This chapter is licensed under the terms of the Creative Commons Attribution 4.0 International License (http://creativecommons.org/licenses/by/4.0/), which permits use, sharing, adaptation, distribution and reproduction in any medium or format, as long as you give appropriate credit to the original author(s) and the source, provide a link to the Creative Commons license and indicate if changes were made.

The images or other third party material in this chapter are included in the chapter's Creative Commons license, unless indicated otherwise in a credit line to the material. If material is not included in the chapter's Creative Commons license and your intended use is not permitted by statutory regulation or exceeds the permitted use, you will need to obtain permission directly from the copyright holder. 